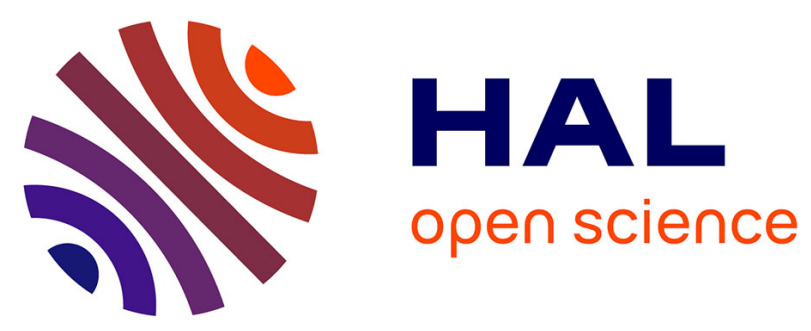

\title{
Phenoxyamidine Zn and Al Complexes: Synthesis, Characterization, and Use in the Ring-Opening Polymerization of Lactide
}

Florian Chotard, Rosita Lapenta, Anaëlle Bolley, Audrey Trommenschlager, Cédric Balan, Jérome Bayardon, Raluca Malacea-Kabbara, Quentin Bonnin, Ewen Bodio, Hélène Cattey, et al.

\section{To cite this version:}

Florian Chotard, Rosita Lapenta, Anaëlle Bolley, Audrey Trommenschlager, Cédric Balan, et al.. Phenoxyamidine $\mathrm{Zn}$ and $\mathrm{Al}$ Complexes: Synthesis, Characterization, and Use in the Ring-Opening Polymerization of Lactide. Organometallics, 2019, 38 (21), pp.4147-4157. 10.1021/acs.organomet.9b00501 . hal-02324069

\section{HAL Id: hal-02324069 https://hal.science/hal-02324069}

Submitted on 24 Nov 2020

HAL is a multi-disciplinary open access archive for the deposit and dissemination of scientific research documents, whether they are published or not. The documents may come from teaching and research institutions in France or abroad, or from public or private research centers.
L'archive ouverte pluridisciplinaire HAL, est destinée au dépôt et à la diffusion de documents scientifiques de niveau recherche, publiés ou non, émanant des établissements d'enseignement et de recherche français ou étrangers, des laboratoires publics ou privés. 


\section{Phenoxyamidine $\mathrm{Zn}$ and Al complexes: synthesis, characterization and use in the ROP of Lactide}

Florian Chotard, ${ }^{\dagger}$ Rosita Lapenta, ${ }^{\S, \#}$ Anaëlle Bolley, ${ }^{\S}$ Audrey Trommenschlager, ${ }^{\dagger}$ Cédric Balan, ${ }^{\dagger}$ Jérôme Bayardon, ${ }^{\dagger}$ Raluca Malacea-Kabbara, ${ }^{\dagger}$ Quentin Bonnin, ${ }^{\dagger}$ Ewen Bodio, ${ }^{+}$Hélène Cattey, ${ }^{+}$Philippe Richard, ${ }^{\dagger}$ Stefano Milione, ${ }^{*}$ Alfonso Grassi, ${ }^{\#}$ Samuel Dagorne* ${ }^{* \S}$ and Pierre Le Gendre ${ }^{*^{+}}$

'Institut de Chimie Moléculaire de I'Université de Bourgogne (ICMUB, UMR-CNRS 6302), Université Bourgogne Franche-Comté

§nstitut de Chimie de Strasbourg (UMR-CNRS 7177), Université de Strasbourg

\# Dipartimento di Chimica e Biologia, Universita ` degli Studi di Salerno, via Giovanni Paolo II, 132-84084 Fisciano (SA), Italy

\section{Supporting Information}

ABSTRACT: Herein we report the synthesis of new ditopic ligands, which consist of a phenoxy group and $N, N, N^{\prime}-$ trisubstituted amidines linked by a methylene spacer (L1-L4). Their coordination chemistry has been studied/investigated with $\mathrm{Zn}(\mathrm{II})$ and $\mathrm{Al}(\mathrm{III})$. Alkane elimination route between the phenol-amidine proligands (L1HL4H) and $\mathrm{Et}_{2} \mathrm{Zn}$ led to dinuclear complexes [(L1-L4)ZnEt] $]_{2}$ (1a-4a) in which the $\mathrm{Zn}$ centers are chelated by phenoxyamidine ligands and bridged through the oxygen atom of the phenoxy groups. Salt metathesis reaction between two equivalents of the sodium amidine phenate $\mathbf{L} \mathbf{N a}$ and $\mathrm{ZnCl}_{2}$ led to a bis-chelate chiral spiro-complex $\left(\mathbf{L} \mathbf{1}_{2} \mathrm{Zn}\right) \mathbf{1} \mathbf{a}^{\prime}$. Analogous alkane elimination route between $\mathrm{AlMe}_{3}$ and the phenol-amidine proligands $\mathbf{L} \mathbf{1 H}-\mathbf{L} \mathbf{4 H}$ allowed the preparation of the mononuclear complexes [(L1-L4)AlMe $\mathbf{A}_{2}$ (1) $\mathbf{1 b} \mathbf{4 b}$ ). The phenoxyamidine-Al and $\mathrm{Zn}$ complexes have been characterized by NMR spectroscopy, elemental analysis and/or high resolution ESI-MS. The solid state structures of the proligands $\left[\mathbf{L 1 H}_{\mathbf{2}}\right][\mathbf{B r}]$ and $\mathbf{L} \mathbf{2} \mathbf{H}$ as well as of six complexes have been established by single crystal X-ray diffraction analysis. Fluxional properties of the proligands $\mathbf{L} \mathbf{1 H} \mathbf{H} \mathbf{L} \mathbf{2 H}$ and of the complexes $\mathbf{1 a}$ and $\mathbf{2 b}$ have been investigated by VT NMR experiments. In the presence of an alcohol source, complexes $\mathbf{1 a - 4 a}$ and $\mathbf{1} \mathbf{b}$-4b were used as initiators for the controlled ring-opening polymerization (ROP) of rac-lactide to afford atactic polylactic acid (PLA).

\section{INTRODUCTION}

Phenoxyimines (I), also known as hemisalen, are among the most versatile ligands in coordination chemistry and afford particularly efficient metal complexes for catalytic purposes (Fig. 1). ${ }^{1,2,3}$ These ligands have also found applications in therapy ${ }^{4}$ and in preparation of liquid crystalline metal complexes. ${ }^{5}$ One advantage of these ligands, beside their ease of access, is the possibility to fine-tune their stereoelectronic properties by introducing different substituents onto the phenoxy ring or at the nitrogen atom of the imine function. Greater alterations of these properties have been brought about by replacing either the phenoxy or the imine moiety by another donor group. As representative examples, $\begin{array}{llll}\text { thiophenoxyimine } & \text { (II) }{ }^{6} \quad \text { anilidoimine } & \text { (III), } & \end{array}$ phenoxyamine (IV) $)^{8}$ and phenoxyiminophosphorane $(\mathrm{V})^{9}$ have been described. The phenoxy moiety has also been combined with a great variety of $\mathrm{N}$ heterocycles to furnish ditopic ligands. ${ }^{10}$ These variants have proven to be very effective, surpassing in several cases the performances of the original phenoxyimine derivatives. With this in mind, we seek to develop a new class of ligand (VI) by replacing the imine function of phenoxyimines with a $N, N, N^{\prime}-$ trisubstituted amidine. The additional $\mathrm{NR}_{2}{ }_{2}$ group in the amidine moiety with respect to the imine function should make it possible to generate a great diversity of structures, provide additional steric bulk close to the metal center and confer enhanced $\pi$-donor ability to the ligand. The methylene spacer as well as the reversed orientation of the imino group $(\mathrm{C}=\mathrm{N})$ of the 
amidine moiety, compared to phenoxyimine, should allow the formation of a 6 -membered chelate ring while preserving the E-configuration of the $N, N, N^{\prime}$ trisubstituted amidine, which is more thermodynamically favorable. ${ }^{11}$

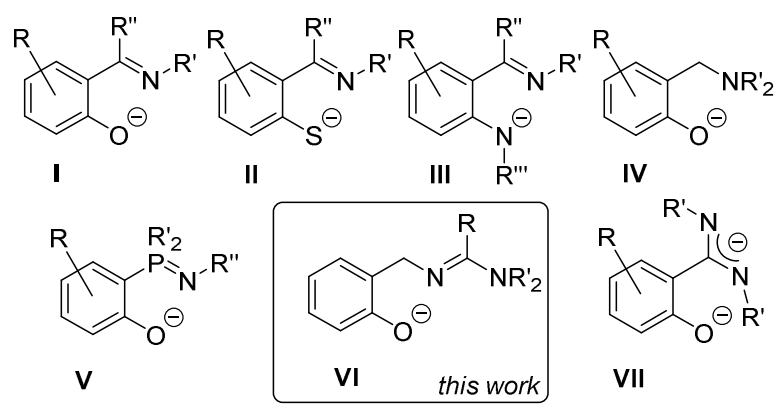

Figure 1. Phenoxyimines (I) and related ligands.

One should highlight that the coordination chemistry of $N, N, N^{\prime}$-trisubstituted amidine remains little explored thus far. ${ }^{12}$ This might be explained by the fact that this chemistry is dominated by the negatively charged amidinate ligands for which $N, N, N^{\prime}-$ trisubstituted amidine are de facto excluded. ${ }^{13}$ Kirillov and Carpentier described previously phenoxyamidinate ligand (VII) and their group 4 and RareEarth metal complexes. ${ }^{14}$ They also showed that the protonated monoanionic form of this ligand (i.e. phenoxyamidine) can coordinate both yttrium and zirconium metal ions, the presence of the $\mathrm{NH}$ functionality being a priori detrimental to olefin polymerization activity. Herein we report the synthesis of a series of phenoxyamidine ligands (VI) bearing a $N, N, N^{\prime}$-trisubstituted amidine and their coordination chemistry toward zinc(II) and aluminum(III) metal ions. The catalytic activity of these complexes in the ROP of rac-lactide was studied and is also reported herein. ${ }^{15}$

\section{RESULTS AND DISCUSSION}

Synthesis of ligands and complexes. The phenolamidine proligands $\mathbf{L} \mathbf{H} \mathbf{H} \mathbf{L} \mathbf{4 H}$ were prepared by two different methods depending on the amidine-carbon substituent (Scheme 1). ${ }^{16}$

\section{Scheme 1. Synthesis of the phenol-amidine proligands $^{\mathrm{a}}$}

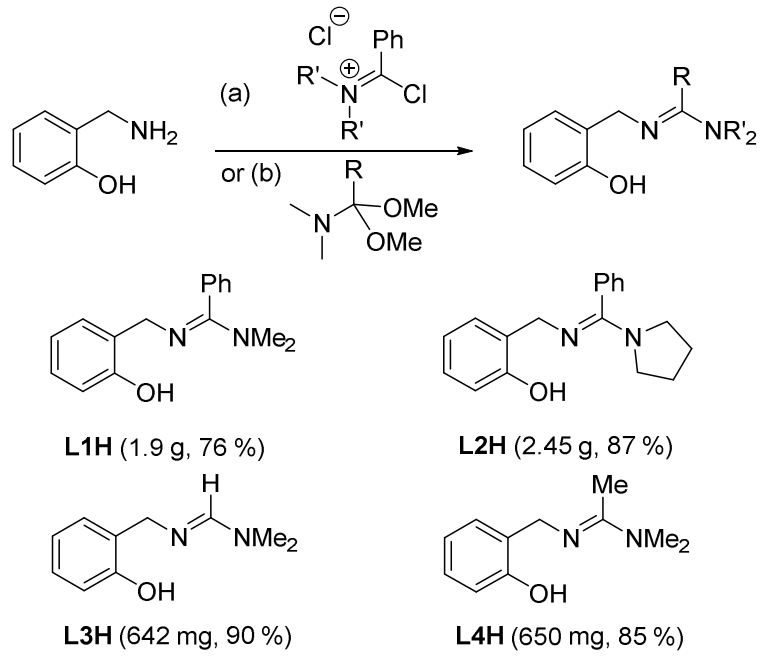

aReagents and conditions: (a) $\mathrm{NEt}_{3}$ (5 equiv.), DCM, 0 ${ }^{\circ} \mathrm{C}$ to r.t., $16 \mathrm{~h}$; (b) DCM, MW, $50{ }^{\circ} \mathrm{C}, 10 \mathrm{~min}$.

For the benzamidine proligands $\mathbf{L} \mathbf{1 H}$ and $\mathbf{L} \mathbf{2 H}$ (method a), Vilsmeier-type reagents were prepared from oxalyl chloride and suitable amide. The resulting chlorobenziminium chloride salts were next reacted with 2-hydroxybenzylamine in the presence of 5 equiv. of triethylamine in dichloromethane to afford L1H and $\mathbf{L 2 H}$ proligands with good yield on a (multi)gram scale. A ${ }^{1} \mathrm{H}$ NMR stability study revealed that $\mathbf{L 1 H}$ is not stable in $\mathrm{CD}_{2} \mathrm{Cl}_{2}$ and leads to the formation of 2-phenyl-4H-3,1-benzoxazine and dimethylamine (Fig. S9, SI). This intramolecular ringclosing reaction is however rather slow and reaches 90\% conversion after 15 days. The phenolformamidine and -acetamidine proligands $\mathbf{L} \mathbf{3} \mathbf{H}$ and L4H ( method b) were obtained in one step from 2hydroxybenzylamine and either $\mathrm{N}, \mathrm{N}$ dimethylformamide dimethyl acetal or $N, N$ dimethylacetamide dimethyl acetal under microwave irradiation $\left(10 \mathrm{~min} ., 50^{\circ} \mathrm{C}\right) .{ }^{17}$ No degradation of $\mathbf{L} 2 \mathrm{H}$ $\mathbf{L} \mathbf{4 H}$ was observed in $\mathrm{CDCl}_{3}$ at room temperature even after a prolonged period of time. The amphoteric character of the phenoxyamidine ligands was evidenced from $\mathbf{L} \mathbf{1 H}$, which was converted into phenoxyamidinium bromide $\left[\mathbf{L}_{\mathbf{1}} \mathbf{H}_{\mathbf{2}}\right][\mathrm{Br}]$ by addition of bromohydric acid or into sodium phenoxyamidine L1Na using $\mathrm{NaH}$ as a base. The proligands $\mathbf{L} \mathbf{H} \mathbf{H} \mathbf{L} \mathbf{H H}$, as well as the protonated and deprotonated form of $\mathbf{L} \mathbf{1 H}$, were characterized by NMR spectroscopy, IR spectroscopy, exact mass and elemental analysis. The ${ }^{1} \mathrm{H}$ NMR spectrum of the phenoxyamidine proligand L1H (Fig. S1, SI) features a broad signal $\left(\Delta v_{1 / 2}=99.12\right.$ 
$\mathrm{Hz}$ ) centered at $\delta=2.85 \mathrm{ppm}$ for the $\mathrm{NMe}_{2}$ group, which is splitted into two singlets at $\delta=2.91$ and 3.48 ppm in the case of [ $\left.\mathbf{L I H}_{2}\right][\mathrm{Br}]$ (Fig. S17, SI) attesting of the higher restricted rotation around the amidine bond when protonated. The pyrrolidine ring protons in L2H (Fig. S25, SI) give four poorly resolved multiplets also showing restricted rotation of the heterocycle. The $\mathrm{NMe}_{2}$ group in $\mathbf{L 3 H}$ (Fig. S35) gives a slightly broadened singlet $\left(\Delta \mathrm{v}_{1 / 2}=6.02 \mathrm{~Hz}\right)$ at $\delta=2.88$ ppm, while a sharp singlet at $\delta=2.95 \mathrm{ppm}\left(\Delta \mathrm{v}_{1 / 2}=\right.$ $1.26 \mathrm{~Hz}$ ) is observed in the case of $\mathbf{L} \mathbf{4 H}$ (Fig. S40, SI). ${ }^{18}$ Other signals in the ${ }^{1} \mathbf{H}$ NMR spectra of $\mathbf{L} \mathbf{H} \mathbf{H}-\mathbf{L} \mathbf{H} \mathbf{H}$ appear well resolved with a characteristic sharp singlet integrated for two protons for the methylene linker at 4.3-4.6 ppm. The fluxional behaviors of $\mathbf{L 1 H}$ and $\mathbf{L 2 H}$ were further probed by a variable temperature ${ }^{1} \mathrm{H}$ NMR study (Fig. S7 and S31). Rotational barriers in $\mathbf{L} \mathbf{H}$ and $\mathbf{L} \mathbf{2} \mathbf{H}$ were calculated to be 55.5(10) and 61.5(5) kJ mol${ }^{-1}$ from Eyring equation, significantly higher than in $N, N$-dimethyl- $N^{\prime}$ benzylbenzamidine for which a rotational barrier of $50.2 \mathrm{~kJ} \mathrm{~mol}^{-1}$ has been determined. ${ }^{19,20}$ The restricted rotation of the amidine bond is also reflected in the ${ }^{13} \mathrm{C}$ NMR spectra of $\mathbf{L} \mathbf{1 H}$ and $\mathbf{L 2 H}$ which display a broad signal at $\delta=38.5 \mathrm{ppm}$ for the $\mathrm{NMe}_{2}$ group in $\mathrm{L} \mathbf{H}$ and four signals at $\delta=49.3,46.9,25.8$ and $24.9 \mathrm{ppm}$ for the pyrrolidine ring in $\mathbf{L 2 H}$ at $298 \mathrm{~K}$. Earlier studies have shown that ${ }^{15} \mathrm{~N}$ chemical shifts difference $\left(\Delta \delta^{15} \mathrm{~N}\right)$ between the imino and the amino nitrogen atoms of an amidine reflects the nitrogen lone pair delocalization and can be correlated with the rotational barrier for analogously substituted amidines. ${ }^{21}$ The comparison of the $\Delta \delta^{15} \mathrm{~N}$ values in $\left[\mathbf{L}_{1} \mathbf{H}_{2}\right][\mathrm{Br}], \quad \mathbf{L} \mathbf{1 H} \quad$ and $N, N$-dimethyl- $N^{\prime}$ benzylbenzamidine indicates a less delocalized $\pi$ system in the latter (Fig.2). The pronounced delocalization of the $\mathrm{NR}_{2}$ lone pair in $\mathbf{L} \mathbf{H}$ is most probably a consequence of an intramolecular hydrogen bonding between the hydroxy group and the amidine function (see below), and may account for the restricted rotation of the amidine moiety.

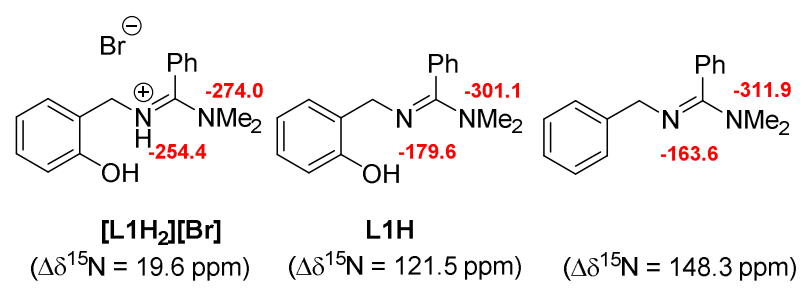

Figure 2. ${ }^{15} \mathrm{~N}$ chemical shifts (ppm) and $\Delta \delta^{15} \mathrm{~N}$ values for $\left[\mathbf{L} \mathbf{L H}_{2}\right][\mathbf{B r}], \mathbf{L} \mathbf{1 H}$ and related $N, N$-dimethyl- $N^{\prime}$ benzylbenzamidine. ${ }^{22}$

The IR spectra of L1H-L4H exhibit a very broad band between 3000 and $2100 \mathrm{~cm}^{-1}$ with the maximum near $2500 \mathrm{~cm}^{-1}$ associated with phenol with hydrogenbonded $\mathrm{OH}$ stretch (Fig. S8, S33, S39 and S44). The structures of $\left[\mathbf{L 1 H}_{2}\right][\mathrm{Br}]$ and $\mathbf{L 2 H}$ were confirmed by $\mathrm{X}$ Ray diffraction analysis (Fig. 3). [ $\left.\mathbf{L 1 H}_{\mathbf{2}}\right][\mathrm{Br}]$ crystallizes in the $P$-1 triclinic space group with two independent molecules in the asymmetric unit while $\mathbf{L} \mathbf{2} \mathbf{H}$ crystalizes in the Pbca orthorhombic space group. Both amidine and amidinium moieties adopt $(E)$ configuration. In the solid state, they feature planar geometry as reflected by the sum of angles around $\mathrm{N}$ atoms close to $360^{\circ}$ and torsional angles $\omega(\mathrm{N} 1-\mathrm{C} 1-\mathrm{N} 2-\mathrm{C} 15)$ close to $180^{\circ}$. For the two molecules, the amidine-carbon phenyl is almost orthogonal to the $\mathrm{N}-\mathrm{C}-\mathrm{N}$ "amidine plane" with a torsional angles $\varphi$ (N1-C1-C9-C15) of $99.8(3)^{\circ}\left[-104.5(3)^{\circ}\right]$ in $\left[\mathbf{L 1 H}_{2}\right][\mathrm{Br}]$ (the bracketed value is given for the second independent molecule present in the asymmetric unit) and $110.35(17)^{\circ}$ in $\mathbf{~} \mathbf{2} \mathbf{H}$. Concerning the phenol group, it is also orthogonal to the "amidine plane" for $\left[\mathbf{L}_{\mathbf{H}}\right][\mathrm{Br}]$, while coplanarity is observed for $\mathbf{L 2 H}$ due to hydrogen bonding between the hydroxy group and the amidine function. The $\mathrm{C}-\mathrm{N}$ bond lengths in L2H (N2-C1 1.350(2) ̊; N1-C1 1.297(2) $\AA$ ) range between single and double bond and are less differentiated than in analogously substituted amidine, which is consistent with a delocalized $\pi$-system. ${ }^{12 a}$ Expectedly, $\mathrm{C}-\mathrm{N}$ bond lengths are almost identical in [ $\left.\mathbf{L 1 H}_{2}\right][\mathrm{Br}](\mathrm{N} 1-\mathrm{C} 1$ 1.323(3) $\AA$ vs

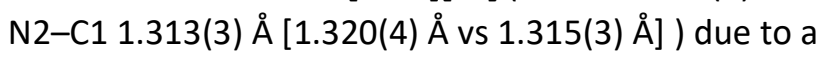
more delocalized $\pi$-system for the amidinium moiety. Noteworthy, the conformation of $\mathbf{L} \mathbf{2 H}$ observed in the solid state seems to predominate in solution at low temperature as attested by NOESY NMR experiment, which showed through-space correlations at $250 \mathrm{~K}$ between the phenolic proton and one pair of $\mathrm{H}_{\alpha}$ protons of the pyrrolidine ring (Fig. S28). 


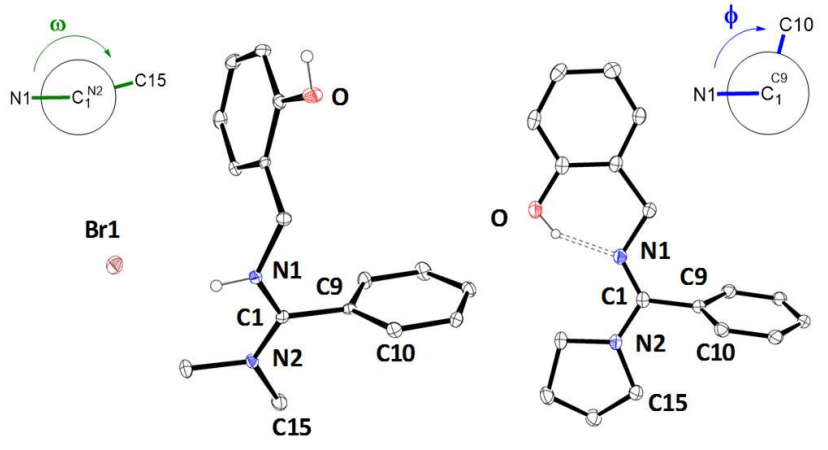

Figure 3. ORTEP views of $\left[\mathbf{L}_{\mathbf{1}} \mathbf{H}_{\mathbf{2}}\right][\mathbf{B r}]$ (left) and $\mathbf{L} \mathbf{2 H}$ (right) and definition of torsion angles $\omega$ and $\varphi$. For [ $\left.\mathbf{L 1 H}_{\mathbf{2}}\right][\mathbf{B r}]$ both independent molecules exhibiting the same conformation, only one molecule is represented. Selected distances (Å) and angles (deg): [ $\left.\mathrm{LLH}_{2}\right][\mathrm{Br}]$ (bracketed data correspond to the second independent molecule): C1-N1 1.323(3) [1.320(4)], C1-N2 1.313(3) [1.315(3)], $\omega-179.7(2)$ [172.9(2)], $\varphi-99.8(3)$ [-104.5(3)], $\Sigma \alpha_{\mathrm{N} 2}$ 359.9(3) [359.8(4)]. L2H: C1-N1 1.2970(19), C1-N2 1.350(2), $\omega$ 172.11(14), $\varphi$ $110.35(17), \Sigma \alpha_{\mathrm{N} 2} 359.6(2)$.

With these proligands in our hands, their coordination chemistry with $\mathrm{Zn}(\mathrm{II})$ was first studied through reaction of equimolar amounts of $\mathbf{L} \mathbf{H} \mathbf{H}-\mathbf{L} \mathbf{H} \mathbf{H}$ and $\mathrm{Et}_{2} \mathrm{Zn}$ in hexane/THF or hexane/DCM at room temperature (Scheme 2). X-Ray analysis of single crystals of $1 \mathrm{a}$ and 2a showed that dinuclear complexes (LZnEt) ${ }_{2}$ were formed in these conditions (Fig. 4). 1a crystalizes in the $P-1$ triclinic space group and two independent half-molecules are present in the asymmetric unit; the two molecules exhibiting very similar conformations. 2a crystalizes in the $P 2_{1} / c$ monoclinic space group, one half molecule is present in the asymmetric unit. All $\mathrm{Zn}$ centers are coordinated in a pseudo tetrahedral geometry by a phenoxyamidine ligand in a $a^{2} O, N^{\prime}-$ chelate fashion, one residual ethyl group and one bridging oxygen atom of the second phenoxyamidine ligand. The phenoxyamidine ligands form with the $\mathrm{Zn}$ (II) center 6-membered metallacycles in a boat-like conformation in the case of $\mathbf{1 a}$ and half chair-like conformation for $\mathbf{2} \mathbf{a}$. This difference of conformation between $\mathbf{1 a}$ and $\mathbf{2 a}$ arises from a torsion of the phenylenemethylene linker in $\mathbf{2 a}$ putting the phenylene ring into the plane defined by $\mathrm{N}, \mathrm{O}$ and $\mathrm{Zn}$ atoms and the methylene group outward. The amidine moiety keeps the same conformation and configuration as observed in $\left[\mathbf{L} \mathbf{1} \mathbf{H}_{2}\right][\mathbf{B r}]$ and $\mathbf{L} \mathbf{2 H}$, thus with one of the alkyl substituents of the amino group on the metal side. It is worth noting that the coordination to $\mathrm{Zn}$ (II) has no influence on the relative $\mathrm{C}-\mathrm{N}$ bond lengths of the amidine moiety: C1-N1 1.300(2) [1.308(2)] $\AA, 1.303(2) \AA$ and $\mathrm{C} 1-\mathrm{N} 2$ 1.356(2) [1.358(2)] $\AA$, 1.343(2) $\AA$ for 1a and 2a, respectively. The bond lengths $\mathrm{Zn}-\mathrm{O}$ and $\mathrm{Zn}-\mathrm{N}$ are in the range of those observed in phenoxyimine $\mathrm{Zn}$ complexes. ${ }^{2 \mathrm{~b}}{ }^{1} \mathrm{H}$ NMR spectra of complexes 1a-4a show fluxionality in solution with a broadening of most of the signals except for the resonance associated with the phenylene linker. DOSY NMR experiments were next conducted on 1a to determine the nuclearity of the complex in solution (Fig. S51 and tables S4-S5, SI). 1a revealed a diffusion coefficient of $1.22 \times 10^{-9} \mathrm{~m}^{2} . \mathrm{s}^{-1}$ $\left(\mathrm{CD}_{2} \mathrm{Cl}_{2}, 298 \mathrm{~K}\right)$ in between the calculated value of the monomer $\left(1,53 \times 10^{-9} \mathrm{~m}^{2} . \mathrm{s}^{-1}\right)$ and the dimer $\left(1,13 \times 10^{-}\right.$ $\left.9 \mathrm{~m}^{2} \cdot \mathrm{s}^{-1}\right)$. This average value suggests a monomer/dimer equilibrium in solution with a fast exchange at the NMR time-scale. Aiming to better understand the structure of $1 \mathrm{a}$ in solution, we carried out variable-temperature ${ }^{1} \mathrm{H}$ NMR study (Fig. 5).

\section{Scheme 2. Synthesis of the (phenoxyamidine)Zn} complexes

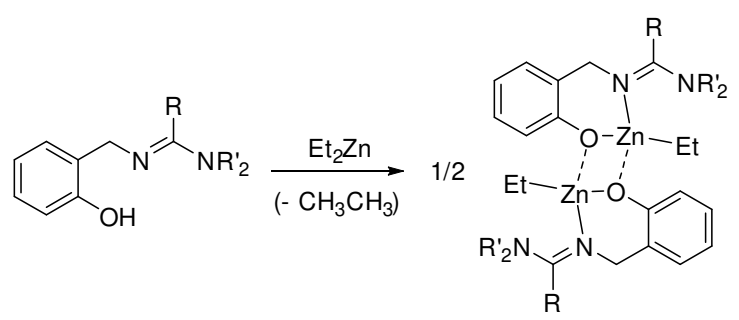

L1H-L4H 1a: $\mathrm{R}=\mathrm{Ph}, \mathrm{R}^{\prime}=\mathrm{Me}(66 \%)$ 2a: $R=P h, R^{\prime}-R^{\prime}=-\left(\mathrm{CH}_{2}\right)_{4^{-}}(44 \%)$ 3a: $R=H, R^{\prime}=\operatorname{Me}(83 \%)$ 4a: $R=M e, R^{\prime}=\operatorname{Me}(86 \%)$

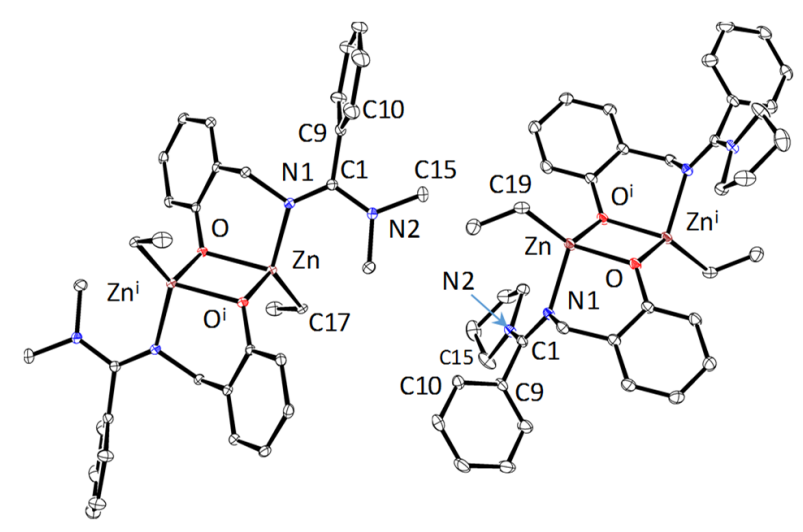


Figure 4. ORTEP views of complexes 1a (left, only one molecule is represented) and $\mathbf{2 a}$ (right) (hydrogen atoms omitted for clarity). Selected distances ( $\AA$ ) and angles (deg): 1a (bracketed data correspond to the second independent molecule): $\mathrm{Zn}-\mathrm{O}$ 2.0434(10) [2.0345(11)], Zn-O' 2.0553(10) [2.0618(11)], Zn-N1 $2.0647(13) \quad[2.0617(13)], \quad \mathrm{Zn}-\mathrm{C} 17 \quad 2.0142(16)$ [2.0366(15)], C1-N1 1.3004(19) [1.308(2)], C1-N2
1.3562(19) [1.358(2)], O-Zn-Oi 83.33(4) [82.65(4)], N1-Zn-C17 131.73(6) [125.19(6)], w 165.43(16) [162.61(14)], $\varphi$ 109.77(19) [-118.46(17)], $\Sigma \alpha_{\mathrm{N} 2} 360.0(2)$ [360.0(3)]. 2a: Zn-O 2.0524(11), Zn-Oi 2.0169(11), Zn-N1 2.1069(12), Zn-C19 2.0104(16), C1-N1 1.3030(18), C1-N2 1.3426(19), O-Zn-O' 82.04(4), N1$\mathrm{Zn}-\mathrm{C} 19$ 107.25(6), $\omega$ 171.06(14), $\varphi-84.7(2), \Sigma \alpha_{\mathrm{N} 2}$ 359.8(2).

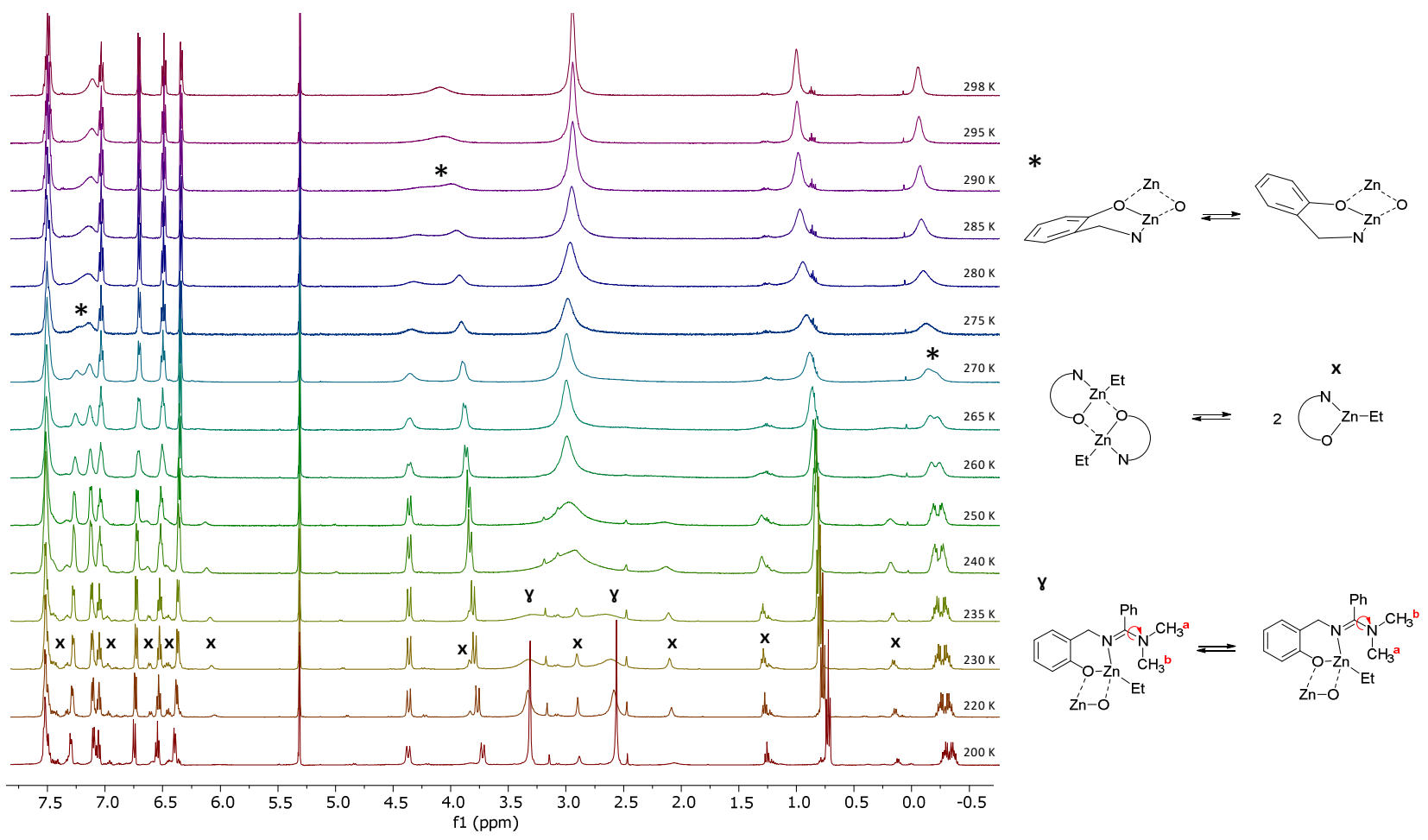

Figure 5. Variable-temperature ${ }^{1} \mathrm{H}$ NMR spectra of $1 \mathrm{a}\left(600 \mathrm{MHz}, \mathrm{CD}_{2} \mathrm{Cl}_{2}\right)$. Dynamic behavior of 1a and monomerdimer equilibrium.

Upon cooling, the benzylic $\mathrm{CH}_{2}$ signal centered at $\delta=$ $4.13 \mathrm{ppm}$ broadens and decoalesces into $A B$ system $(\mathrm{Tc}=292.5 \mathrm{~K})$. A split of the signal of the methylene protons of the ethyl zinc ligand was observed at lower temperatures $(\mathrm{Tc}=272.5 \mathrm{~K})$. This diastereotopic splitting arises from steric constraints and restricted movement of the phenylenemethylene linkers at low temperature giving rise to $\mathrm{sp}^{2}-\mathrm{sp}^{3}$ atropoisomerism (motion and related signals labelled by "*" on Fig. 5). Additional restricted rotation of the phenyl-amidine bond gives rise to two resonances for the diastereotopic ortho-phenyl protons ( $\mathrm{Tc}=277.5 \mathrm{~K}$ ). The energy barrier for the flipping motion of the 6membered metallacycle was estimated to $55.6(5) \mathrm{kJ}$ $\mathrm{mol}^{-1}$ from Eyring equation, which is consistent with the non-persistence of the chiral bent structure of the phenoxyamidine ethyl $\mathrm{Zn}$ fragment in the dinuclear complex 1a at ambient temperature. ${ }^{23}$ Upon further cooling (from $265 \mathrm{~K}$ ), part of the signals decoalesces giving rise to a new set of signals that can be tentatively assigned to the monomeric complex species (signals of the monomer labelled by " $x$ " on the spectrum registered at $230 \mathrm{~K}$, Fig. 5). ${ }^{24} \mathrm{New}$ ethyl zinc ligand signals at $\delta=0.17$ and $1.31 \mathrm{ppm}$ are clearly visible and correspond to a proportion of $33 \%$ of monomer at $250 \mathrm{~K}$ that tends to decrease at lower temperatures $(21 \%$ at $200 \mathrm{~K})$. With respect to the restricted rotation around the amidine bond, $\mathrm{NMe}_{2}$ signal centered at $\delta=2.95 \mathrm{ppm}$ collapses below $240 \mathrm{~K}$ $\left(T_{C}=237.5 \mathrm{~K}\right)$ and then split into two singlets (labelled 
by " $\gamma$ " on Fig. 5). The corresponding smaller barrier found in 1a $\left(44.4(5) \mathrm{kJ} \mathrm{mol}^{-1}\right)$ compared to $\mathbf{~} \mathbf{1 H}$ $\left(55.5(5) \mathrm{kJ} \mathrm{mol}^{-1}\right)$ might appear surprising at first sight, but can be rationalized considering the hydrogen bonding in the latter.

Previous studies have shown that phenoxyimine ligands have a propensity to give rather homoleptic zinc complexes $\left(L_{2} Z n\right)$ than heteroleptic complexes $(\operatorname{LnX}){ }^{25,26}$ This phenomenon was not observed with L1H-L4H, so we wanted to check if bis(phenoxyamidine) $\mathrm{Zn}$ homoleptic complex can nevertheless be formed. To this end, we carried out the reaction between sodium phenoxyamidine salt L1Na and $\mathrm{ZnCl}_{2}$ in 2:1 ratio and got the bis(phenoxyamidine)Zn complex 1 $\mathbf{1 a}^{\prime}$ in $35 \%$ yield after recrystallization (Scheme 3). Suitable crystals for X-Ray diffraction study were obtained by layering pentane to saturated dichloromethane solution of 1a' (Fig. 6).

\section{Scheme 3. Synthesis of a (phenoxyamidine) $2 \mathrm{Zn}$} complex

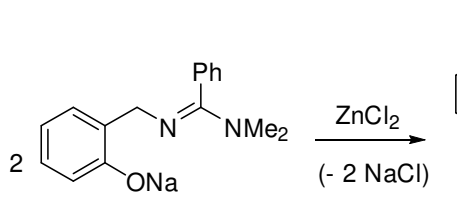

$\mathrm{L} 1 \mathrm{Na}$

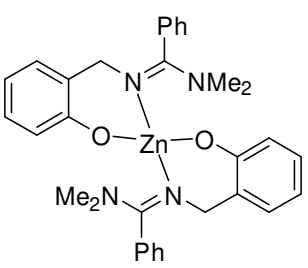

1a' $(35 \%)$

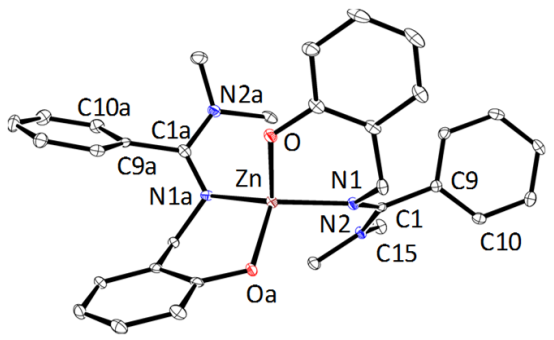

Figure 6. ORTEP view of 1a' (hydrogen atoms are omitted for clarity). Selected distances $(\AA)$ and angles (deg), bracketed data correspond to the second ligand labeled by "a": Zn-O 1.949(2), Zn-Oa 1.940(2), Zn-N1 2.013(3), Zn-N1a 2.009(3), N1-C1 1.313(4) [1.311(4)], N2-C1 1.351(4) [1.355(4)], O-Zn-Oa 119.07(9), N1Zn-N1a 134.46(9), w 162.3(3) [-151.6(3)], $\varphi$ 114.4(3) [-121.9(3)], $\Sigma \alpha_{\mathrm{N} 2} 359.6(4)$ [359.9(4)].

1a' crystallizes in the $P 2_{1} / c$ monoclinic space group. $Z n$ atom links two phenoxyamidine ligands in a pseudo tetrahedral geometry giving rise to a chiral spirocomplex with an approximate C2 symmetry. Both metallacycles adopt a half chair-like conformation similar to the one observed for complex $\mathbf{2 a}$. The chirality of the complex $1 a^{\prime}$ is reflected in the ${ }^{1} \mathrm{H} N M R$ spectrum by a diasterotopic splitting of the benzylic $\mathrm{CH}_{2}$ protons signals into a set of two doublets ( $A B$ spin system, Fig. S68). Diastereotopicity is also observed for the ortho-protons of the phenyl ring, due to the restricted rotation of the phenyl-amidine bond.

Phenoxyamidine ligands were coordinated to $\mathrm{Al}$ (III) via an alkane elimination route similar to the one used in $\mathrm{Zn}$ series. Thus, the phenol-amidine proligands $\mathbf{L} \mathbf{H} \mathbf{H}-$ L4H were reacted with $\mathrm{AlMe}_{3}$ in THF or DCM at room temperature to yield the phenoxyamidine dimethyl aluminium complexes $\mathbf{1} \mathbf{b}-\mathbf{4 b}$ in 75 to $85 \%$ yields (Scheme 4). Compared with $\mathrm{Zn}(\mathrm{II})$ analogues, the ${ }^{1} \mathrm{H}$ NMR spectra of $\mathrm{Al}$ (III) complexes show sharper signals along with a more upfield shielded signal of the methylene linker $(\Delta \delta=0.2 \mathrm{ppm})$. A single ${ }^{1} \mathrm{H}$ NMR signal from $\mathrm{NMe}_{2}$ group in complexes $\mathbf{1 b}, \mathbf{3 b}$ and $\mathbf{4 b}$ and only two signals for the pyrrolidine ring in $\mathbf{2 b}$ are displayed on spectra, which is consistent with a fast rotation around the amidine bond with respect to NMR time scale at room temperature (Fig. S73, S79, S85, S90). Consistently, phenyl-amidine bond rotational barrier of $51.9(5) \mathrm{kJ} \mathrm{mol}^{-1}$ was determined in complex $\mathbf{2 b}$ by VT NMR study (Fig. S83). ${ }^{19}$ X-Ray diffraction study of complexes $\mathbf{1 b}$ (monoclinic, $P 2_{1} / c$ ) and $\mathbf{2 b}$ (monoclinic, $P 2_{1} / n$ ) revealed a pseudotetrahedral geometry around the Al atom, which forms with the phenoxyamidine ligand a 6-membered metallacycle in a boat like conformation (Fig. 7).

\section{Scheme 4. Synthesis of the (phenoxyamidine)Al} complexes

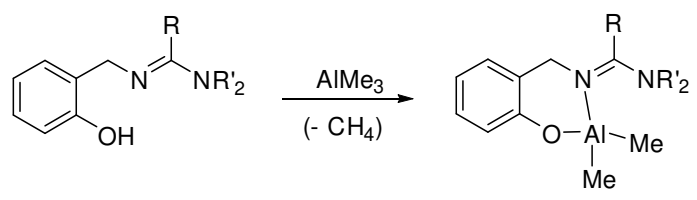

L1H-L4H

1b: $R=P h, R^{\prime}=\operatorname{Me}(77 \%)$ 2b: $R=P h, R^{\prime}-R^{\prime}=-\left(\mathrm{CH}_{2}\right)_{4^{-}}-(75 \%)$ 3b: $\mathrm{R}=\mathrm{H}, \mathrm{R}^{\prime}=\operatorname{Me}(76 \%)$ 4b: $R=M e, R^{\prime}=\operatorname{Me}(85 \%)$ 


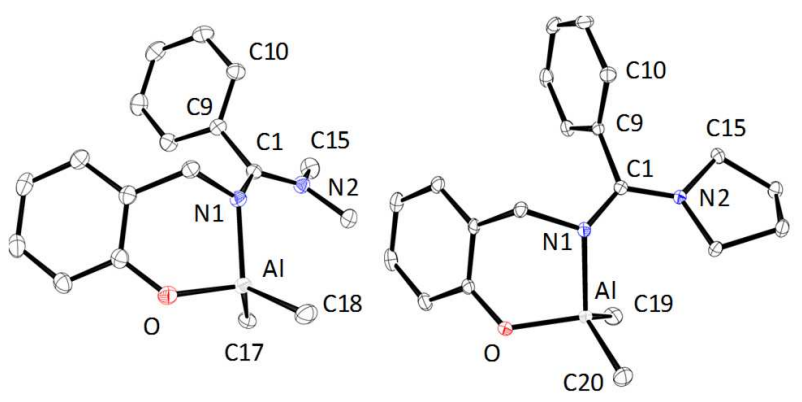

Figure 7. ORTEP views of $\mathbf{1 b}$ (left) and $\mathbf{2} \mathbf{b}$ (right) (hydrogen atoms omitted for clarity). Selected distances (Å) and angles (deg): 1b: Al-O 1.7769(13), Al-N1 1.9601(14), Al-C17 2.0051(19), Al-C18 1.9757(19), N1-C1 1.324(2), N2-C1 1.337(2), O-Al-N1 96.58(6), C17-Al-C18 117.74(8), $\omega$ 163.83(15), $\varphi$ $112.22(18), \Sigma \alpha_{\mathrm{N} 2} 360.0(2) .2 b:$ Al-O 1.7874(13), Al-N1 1.9674(15), Al-C19 1.9690(19), Al-C20 1.962(2), N1C1 1.314(2), N2-C1 1.334(2), O-Al-N1 97.06(6), C19Al-C20 119.06(9), w 170.82(15), $\varphi$ 106.77(19), $\Sigma \alpha_{N 2}$ 359.9(2).

The geometry of the amidine fragment is similar to the one observed in $\mathrm{Zn}$ complexes $\mathbf{1 a}$ and $\mathbf{2 a}$ but with smaller difference between $\mathrm{C}=\mathrm{N}$ and $\mathrm{C}-\mathrm{N}$ bond lengths $\left(\Delta_{C N}=0.013(3) \AA\right.$ and 0.019 (3) $\AA$ in $\mathbf{1 b}$ and $\mathbf{2 b}$, respectively). Analogous phenoxyimine dimethyl aluminum complex reported by Nomura shows similar tetrahedral geometry around Al, a nearly planar 6membered metallacycle, shorter $\mathrm{Al}-\mathrm{C}$ bond lengths and a longer $\mathrm{Al}-\mathrm{N}$ bond length probably due to the less electron donating ability of imines with respect to amidines. ${ }^{2 c}$

ROP of Lactide. The heteroleptic $\mathrm{Zn}$ (II) and $\mathrm{Al}$ (III) complexes $\mathbf{1} \mathbf{a}-\mathbf{4} \mathbf{a}$ and $\mathbf{1} \mathbf{b}-\mathbf{4} \mathbf{b}$, respectively, were tested as ROP initiators for rac-lactide ROP in the presence of 1 equiv. of ${ }^{i} \mathrm{PrOH}$ or $\mathrm{BnOH}$ as the alcohol source. The results are compiled in Table 1 . All $\mathrm{Zn}$ (II) species readily polymerize lactide (100 equiv) at room temperature within 2 to $7 \mathrm{~h}$ to afford atactic PLA, as deduced from NMR and SEC data (Fig. S101-106). The phenoxyamidine $\mathrm{Zn}$ complexes $\mathbf{1 a}-\mathbf{4 a}$ give rise to apparent TOF up to $50 \mathrm{~mol}$ of LA (mol of $\mathrm{Zn})^{-1} \mathrm{~h}^{-1}$. These values are higher than that of the phenoxyimine chelate $\mathrm{Zn}$ complexes reported by Chisholm ${ }^{26}$ (apparent TOF up to $6 \mathrm{~mol}$ of LA (mol of $\mathrm{Zn})^{-1} \mathrm{~h}^{-1}$ ) but do not compare with the most active $\mathrm{Zn}$ catalysts reported to date. ${ }^{27}$
Table 1. ROP of lactide mediated by $\mathbf{1 a - 4 a}$ and $\mathbf{1} \mathbf{b}-\mathbf{4} \mathbf{b}^{a}$

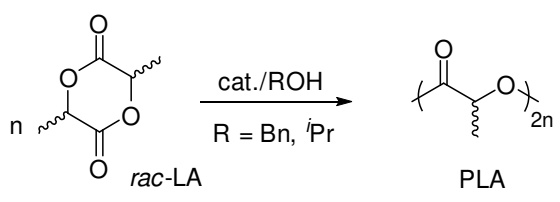

\begin{tabular}{|c|c|c|c|c|c|c|c|}
\hline $\begin{array}{l}R u \\
n\end{array}$ & Cat & $\mathrm{ROH}$ & $\begin{array}{l}\text { Tim } \\
e \\
(h)^{b}\end{array}$ & $\begin{array}{l}T \\
1^{\circ} \mathrm{C} \\
1\end{array}$ & $\begin{array}{l}\text { Con } \\
v \\
(\%)^{c}\end{array}$ & $\begin{array}{l}M_{n,} \\
\exp ^{e} \\
\left(M_{n,}\right. \\
\text { theo }\end{array}$ & $\boldsymbol{\Xi}^{f}$ \\
\hline 1 & $1 a^{g}$ & $\begin{array}{l}\text { iPrO } \\
\text { H }\end{array}$ & 2 & RT & 99 & $\begin{array}{l}9300 \\
(1420 \\
0)\end{array}$ & $\begin{array}{l}1.5 \\
3\end{array}$ \\
\hline 2 & $2 a^{g}$ & $\begin{array}{l}\text { 'PrO } \\
\mathrm{H}\end{array}$ & 2 & RT & 96 & $\begin{array}{l}14700 \\
(1380 \\
0)\end{array}$ & $\begin{array}{l}1.0 \\
2\end{array}$ \\
\hline 3 & $2 a^{g}$ & $\begin{array}{l}\mathrm{BnO} \\
\mathrm{H}^{i}\end{array}$ & $7^{i}$ & RT & 100 & $\begin{array}{l}12700 \\
(1430 \\
0)\end{array}$ & $\begin{array}{l}1.0 \\
8\end{array}$ \\
\hline 4 & $3 a^{g}$ & $\begin{array}{l}\text { 'PrO } \\
\text { H }\end{array}$ & 2 & RT & 96 & $\begin{array}{l}15250 \\
(1380 \\
0)\end{array}$ & $\begin{array}{l}1.8 \\
3\end{array}$ \\
\hline 5 & $4 a^{g}$ & $\begin{array}{l}\text { 'PrO } \\
\mathrm{H}\end{array}$ & 2 & $\mathrm{RT}$ & 98 & $\begin{array}{l}12900 \\
(1410 \\
0)\end{array}$ & $\begin{array}{l}1.6 \\
5\end{array}$ \\
\hline 6 & $\mathbf{1}^{h}{ }^{h}$ & $\begin{array}{l}\text { 'PrO } \\
\text { H }\end{array}$ & 24 & 70 & 94 & $\begin{array}{l}4700 \\
(1355 \\
0)\end{array}$ & $\begin{array}{l}1.2 \\
9\end{array}$ \\
\hline 7 & $\mathbf{2}^{\mathbf{b}^{h}}$ & $\begin{array}{l}\text { 'PrO } \\
\text { H }\end{array}$ & 24 & 70 & 56 & $\begin{array}{l}7400 \\
(8100)\end{array}$ & $\begin{array}{l}1.0 \\
6\end{array}$ \\
\hline 8 & $\mathbf{2}^{h}{ }^{h}$ & $\begin{array}{l}\text { 'PrO } \\
\text { H }\end{array}$ & 12 & 90 & 97 & $\begin{array}{l}12900 \\
(1400 \\
0)\end{array}$ & $\begin{array}{l}1.0 \\
5\end{array}$ \\
\hline 9 & $2 \mathbf{b}^{h}$ & $\begin{array}{l}\mathrm{BnO} \\
\mathrm{H}\end{array}$ & 10 & 90 & 100 & $\begin{array}{l}12100 \\
(1440 \\
0)\end{array}$ & $\begin{array}{l}1.0 \\
7\end{array}$ \\
\hline
\end{tabular}




\begin{tabular}{|c|c|c|c|c|c|c|}
\hline 10 & $3 b^{h}$ & $\begin{array}{l}\text { 'PrO } \\
\text { H }\end{array}$ & 24 & 70 & 89 & $\begin{array}{l}3500 \\
(1283 \\
0)\end{array}$ \\
\hline 1 & $4 b^{h}$ & $\begin{array}{l}\text { 'PrO } \\
\text { H }\end{array}$ & 24 & 70 & 98 & $\begin{array}{l}6900 \\
(1410 \\
0)\end{array}$ \\
\hline
\end{tabular}

aPolymerization conditions: $[\text { rac-LA }]_{0}=1 \mathrm{M}, 100$ equiv of rac-LA, 1 equiv of $\mathrm{ROH}$ (' $\mathrm{PrOH}$ or $\mathrm{BnOH}$ ) and 1 equiv of metal catalyst. ${ }^{b}$ Reaction time. ${ }^{c}$ Monomer conversion. ${ }^{d}$ Calculated using $\mathrm{M}_{n, \text { theo }}=[$ rac$L A]_{0} /[\text { catalyst }]_{0} \times M_{L A} \times$ conversion. ${ }^{e}$ Measured by GPC in THF $\left(30{ }^{\circ} \mathrm{C}\right)$ using PS standards and corrected by applying the appropriate correcting factor (0.58). ${ }^{f}$ Measured by GPC in THF $\left(30{ }^{\circ} \mathrm{C}\right) .{ }^{g}$ in $\mathrm{CH}_{2} \mathrm{Cl}_{2}$, room temperature. ${ }^{h}$ in toluene. ${ }^{i}$ not optimized.

A comparison between $\mathbf{1 a}, \mathbf{3 a}$ and $\mathbf{4 a}$ shows that modification of the ligand backbone has little influence on activity. These results contrast with those of Lin and co-workers, who has shown that tridentate Schiff base $\mathrm{Zn}$ complexes bearing Ph or Me substituent on the imine-carbon showed much higher catalytic activities than salicylaldimine derivatives. ${ }^{2 b, 28}$ For all $\mathrm{Zn}(\mathrm{II})$ species (1a-4a), the formed PLA is chain-length controlled in good agreement with the expected values, though narrow disperse PLA $(\theta<1.1)$ is only produced with catalyst $\mathbf{2 a}$, which incorporates a phenyl group on the amidine carbon and a more sterically hindered pyrrolidine-amidine moiety (entries 2 and 3, Table 1). Kinetic data gathered for catalysts $\mathbf{1 a}$ and $\mathbf{2 a}$ agree with a controlled ROP in both cases, including: i) a linear correlation between the PLA Mn values and lactide conversion as the ROP proceeds (Fig. $\mathrm{S98}$ and S100); ii) a reaction rate law observed to be first order in monomer (Fig. S99).

${ }^{1} \mathrm{H}$ NMR monitoring experiments of a $1 / 1 \mathrm{1a} / \mathrm{P} \mathrm{PrOH}$ mixture in $\mathrm{CD}_{2} \mathrm{Cl}_{2}$ showed ethane evolution and the formation of an alkoxy complex 1a" along with other species that were identified as the homoleptic

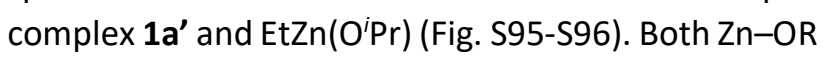
species 1a" and EtZn(O'Pr) may account for the observed lactide ROP activity of the $1 \mathrm{a} /$ / $^{\mathrm{P}} \mathrm{POH}$ catalytic system. X-Ray diffraction study conducted on a single crystal of 1a" (triclinic, $P$-1) grown from the NMR sample confirmed the formation of an alkoxy complex revealing a dinuclear $\mathrm{Zn}$ complex bridged by the oxygen atom of the isopropoxy groups (Fig. 8). The geometry around the $\mathrm{Zn}$ atoms is pseudo tetrahedral. Both (phenoxyamidine)Zn metallacycles feature boat like conformation folded in the same direction. The amidine moiety in 1a" is in E-configuration with planar arrangement and with slightly smaller difference between the $\mathrm{C}=\mathrm{N}$ and $\mathrm{C}-\mathrm{N}$ bond lengths $\left(\Delta_{\mathrm{CN}}=\right.$ $0.036(3)$ and $0.030(3) \AA)$ than in 1a $\left(\Delta_{C N}=0.056(3) \AA\right)$. In the case of $2 \mathrm{a} / \mathrm{BnOH}, \mathrm{MALDI}-\mathrm{TOF}$ data of the produced PLA are consistent with a BnO-end-capped linear PLA. The latter is in line with a ROP process occurring through a coordination-insertion mechanism from an in situ formed $\mathrm{Zn}-\mathrm{OBn}$ species that acts as the actual catalyst.

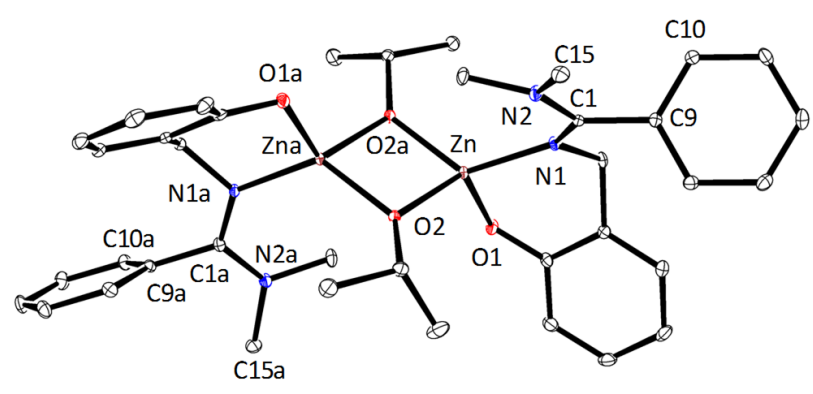

Figure 8. ORTEP view of 1a" (hydrogen atoms are omitted for clarity). Selected distances ( $\AA$ ) and angles (deg), bracketed data correspond to the second moiety labeled by "a": Zn-02 1.9548(11), Zn-02a 1.9561(13), Zn-O1 1.9276(12) [1.9252(12)], Zn-N1 2.0090(14) [2.0043(13)], Zna-02 1.9514(12), Zna-02a 1.9639(12), N1-C1 1.310(2) [1.314(2)], N2-C1 1.345(2) [1.343(2)], O2a-Zn-O2 82.86(5), O2a-ZnaO2 82.75(5), O1-Zn-N1 99.24(5) [99.21(6)], $\omega$ 170.67(16) [163.74(16)], $\varphi$ 105.64(19) [110.91(19)], $\sum \alpha_{\mathrm{N} 2} 360.0(3)$ [360.0(3)].

When using catalyst $\mathbf{4 a}$, the ROP of lactide proceeds with a moderate control leading to the production of broadly disperse PLA, which is likely due to the formation of linear and cyclic PLA as deduced from MALDI-TOF data (Fig. S105-S106). As summarized in Table 1, Al(III) complexes $\mathbf{1 b} \mathbf{b} \mathbf{4} \mathbf{b}$ all mediate the ROP of lactide $\left(70^{\circ} \mathrm{C}\right.$ or $90{ }^{\circ} \mathrm{C}$, toluene) in the presence of ' $\mathrm{PrOH} / \mathrm{BnOH}$, albeit with a moderate activity (apparent TOF up to $10 \mathrm{~mol}$ of LA (mol of Al) $)^{-1} \mathrm{~h}^{-1}$ ) comparable to those reported by Carpentier, ${ }^{29}$ Nomura, ${ }^{30}$ Chen, ${ }^{6}$ Redshaw $^{31}$ and Pappalardo ${ }^{2 \mathrm{~d}}$ with $\mathrm{Al}\left(\right.$ III) Schiff base initiators. ${ }^{32}$ Similarly to the $\mathrm{Zn}$ (II) 
analogues, the pyrrolidine-incorporating derivative $\mathbf{2} \mathbf{b}$ performs best whether regarding ROP control and activity to afford narrow disperse and chain-length controlled PLA in good agreement with the expected PLA $M_{\mathrm{n}}$ S (entries 7-9, Table 1). In contrast, PLAs with a broader polydispersity (ranging from 1.29 to 2.17) and lower $M_{\mathrm{n}}$ values than theoretically expected are produced using less sterically hindered catalysts $\mathbf{1} \mathbf{b}$, $\mathbf{3 b}$ and $\mathbf{4 b}$ in combination with ${ }^{\mathrm{P}} \mathrm{POH}$ (entries 6, 10 and 11 , Table 1), indicating a poorly controlled ROP process. The latter likely indicates an ill-defined ROP catalytic system, presumably due to the sluggish activation of $\mathbf{A l}$ dialkyl precursors $\mathbf{1 b}, \mathbf{3} \mathbf{b}$ and $\mathbf{4 b}$ by ${ }^{i} \mathrm{PrOH}$, as suggested by ${ }^{1} \mathrm{H}$ NMR monitoring experiments. Kinetic data for lactide ROP initiated by $\mathbf{2 b} / \mathrm{BnOH}$ all support a well-controlled ROP process (Fig. S108-S112) and MALDI-TOF data are consistent with a BnO-ended linear PLA (S113 and S114). Overall, within the ligand series, the better ROP performances of the pyrrolidine-bearing metal complexes ( $2 a$ and 2b) clearly indicate that substantial steric protection of the $\mathrm{Zn}(\mathrm{III} / \mathrm{Al}(\mathrm{III})$ metal centers is beneficial to lactide ROP control and the production of narrow disperse PLA.

\section{Conclusion}

We have developed the synthesis of new ditopic ligands, which combine a phenoxy group and a $N, N, N^{\prime}-$ trisubstituted amidine spaced by a methylene linker. The coordination chemistry of these ligands has been investigated with $\mathrm{Zn}$ (II) and $\mathrm{Al}(\mathrm{III})$ metal ions resulting in a variety of discrete metal complexes. Phenoxyamidines behave as bidentate ligands coordinated through $\mathrm{O}$ and $\mathrm{N}^{\prime}$ donor atoms. In the solid state, phenoxyamidines feature planar geometry and $E$-configuration with little difference between $\mathrm{C}=\mathrm{N}$ and $\mathrm{C}-\mathrm{N}$ bond lengths highlighting the conjugated character of the amidine function. In the $\mathrm{Zn}$ (II) and $\mathrm{Al}$ (III) complexes, the amino $\mathrm{NR}_{2}$ group of the amidine function does not bind to the metal but provides steric bulk about it. NMR studies have shown that the phenoxyamidine complexes are fluxional in solution with both a flipping motion of the metallacycle and the rotation about the $\mathrm{C}-\mathrm{N}$ amidine bond. With respect to lactide polymerization activity, the heteroleptic phenoxyamidine $\mathrm{Zn}$ (II)-/AI(III)-alkyl complexes in combination with an alcohol source were found all active in lactide ROP catalysis and afforded atactic PLA. A superior ROP control was achieved with the more sterically protected $\mathrm{Zn}(\mathrm{II})$ and $\mathrm{Al}(\mathrm{III})$ complexes $\mathbf{2} \mathbf{a}$ and $\mathbf{2 b}$.

\section{EXPERIMENTAL SECTION}

General consideration. All reactions, except when indicated, were carried out under an atmosphere of argon using conventional Schlenk techniques and $\mathrm{Ar}$ glovebox. DCM, diethyl ether, THF, toluene, and pentane were dried using a MBRAUN SPS 800 . Microwave experiments were performed on a monowave 300 Anton-Paar apparatus (monomode microwave) with infrared detection of temperature. Analyses were performed at the "Plateforme d'Analyses Chimiques de Synthèse Moléculaire de I'Université de Bourgogne" and for some elemental analyses also at the London Metropolitan University, especially for sensitive compounds. The identity and purity of the compounds were established using elemental analyses, multinuclear NMR spectroscopy, $X$-ray diffraction analysis, and high-resolution mass spectrometry. NMR spectra $\left({ }^{1} \mathrm{H},{ }^{13} \mathrm{C},{ }^{15} \mathrm{~N}\right)$ were recorded on Bruker 300 Avance III, Bruker 500 Avance III, or Bruker 600 Avance III spectrometers. All acquisitions were performed at $300 \mathrm{~K}$. Chemical shifts are quoted in parts per million $(\delta)$ relative to TMS (for ${ }^{1} \mathrm{H}$ and ${ }^{13} \mathrm{C}$ ). For ${ }^{1} \mathrm{H}$ and ${ }^{13} \mathrm{C}$ spectra, values were determined by using solvent residual signals (e.g. $\mathrm{CHCl}_{3}$ in $\mathrm{CDCl}_{3}$ ) as internal standards. Assignment of ${ }^{1} \mathrm{H}$ and ${ }^{13} \mathrm{C}$ signals (when possible) was done through the use of 2D experiences (COSY, HSQC and HMBC). High resolution mass spectra were recorded on a Thermo LTQ Orbitrap XL ESI-MS (ElectroSpray lonization Mass Spectrometry). Chlorobenziminium chloride derivatives were synthesized according to previously reported procedure. ${ }^{33}$ All other reagents were commercially available and used as received.

X-Ray experimental procedure. Crystal of all compound were selected and mounted on a mylar loop with oil on either a 'Bruker APEX-II CCD' or a 'Bruker D8 venture Photon 100' diffractometer. Crystal were kept at $115 \mathrm{~K}$ or $100 \mathrm{~K}$ during data collection. Using Olex $2{ }^{34}$ the structures were solved with the SheIXT ${ }^{35}$ structure solution program using Direct Methods and refined with the $\mathrm{XL}^{36}$ refinement package using Least Squares minimization. More details can be found in the Supporting Information 
and in the Crystallographic Information Files in which are imbedded the .res and .hkl files.

\section{Synthesis of (E)-N'-(2-hydroxybenzyl)-N,N-} dimethylbenzamidine L1H (light yellow solid, $1.9 \mathrm{~g}$, yield: $76 \%$ ). $\mathrm{N}, \mathrm{N}$-dimethylchlorobenziminium chloride (1 equiv., $10 \mathrm{mmol}, 2.12 \mathrm{~g}$ ) was solubilized in DCM (30 $\mathrm{mL}$ ) and cooled to $0{ }^{\circ} \mathrm{C}$. Triethylamine (5 equiv., 50.0 $\mathrm{mmol}, 6.95 \mathrm{~mL}$ ) was added, and then slowly $50 \mathrm{~mL}$ of DCM solution of 2-hydroxybenzylamine (1 equiv., 10 $\mathrm{mmol}, 1.23 \mathrm{~g})$. The mixture was stirred at $0^{\circ} \mathrm{C}$ for $15^{\prime}$ and then at r.t. for $1 \mathrm{~h} 30$. After hydrolysis and extraction with $D C M$, the combined organic layer was dried (anhydrous $\mathrm{MgSO}_{4}$ ), filtered, and concentrated in vacuo. The residue was washed successively with ether and pentane to give L1H. HRMS (ESI-pos): calcd for $\left[\mathrm{C}_{16} \mathrm{H}_{19} \mathrm{~N}_{2} \mathrm{O}\right]^{+}[\mathrm{M}+\mathrm{H}]^{+}:$255.14919. Found: 255.14804 (-4.5 ppm). Elemental Analysis: calcd for $\mathrm{C}_{16} \mathrm{H}_{18} \mathrm{~N}_{2} \mathrm{O}: \mathrm{C}, 75.56 ; \mathrm{H}, 7.13 ; \mathrm{N}, 11.01 \%$. Found: $\mathrm{C}$, $75.22 ; \mathrm{H}, 7.51 ; \mathrm{N}, 10.78 \%$. ${ }^{1} \mathrm{H}$ NMR $\left(600 \mathrm{MHz}, \mathrm{CD}_{2} \mathrm{Cl}_{2}\right)$ : $\delta(\mathrm{ppm})=7.51-7.45(\mathrm{~m}, 3 \mathrm{H}, m-\mathrm{Ph}$ and $p-\mathrm{Ph}), 7.18-7.16$ $(\mathrm{m}, 2 \mathrm{H}, \mathrm{o}-\mathrm{Ph}), 7.04\left(\mathrm{~m}, 1 \mathrm{H}, \mathrm{Ar} \mathrm{H} \mathrm{H}_{4}\right), 6.74\left(\mathrm{~d},{ }^{3}\right)_{\mathrm{H}-\mathrm{H}}=8.2$ $\left.\mathrm{Hz}, 1 \mathrm{H}, \mathrm{Ar} \mathrm{H}_{3}\right)$, 6.66-6.62 (m, 2H, Ar $\mathrm{H}_{5}$ and $\left.\mathrm{Ar} \mathrm{H}_{6}\right), 4.23$ (s, $2 \mathrm{H}, \mathrm{ArCH}_{2}$ ), 2.85 (broad s, 6H, NMe ${ }_{2}$ ). ${ }^{13} \mathrm{C}\left\{{ }^{1} \mathrm{H}\right\}$ NMR (151 MHz, $\left.\mathrm{CD}_{2} \mathrm{Cl}_{2}\right), \delta(\mathrm{ppm}): 163.1\left(\mathrm{C}_{\mathrm{q}}, \mathrm{C}=\mathrm{N}\right), 158.9\left(\mathrm{C}_{\mathrm{q}}\right.$, $\mathrm{C}-0$ ), 133.6 ( $\left.\mathrm{C}_{q}, i-\mathrm{Ph}\right), 129.4$ (CH, $p$-Ph), 129.4 (CH, m$\mathrm{Ph}), 127.8\left(\mathrm{CH}, o-\mathrm{Ph}\right.$ overlapping with $\left.\operatorname{Ar} \mathrm{C}_{4}\right), 127.5$ $\left(\mathrm{CH}, \operatorname{Ar} \mathrm{C}_{6}\right), 125.6\left(\mathrm{C}_{9}, \operatorname{ArC}_{1}\right), 118.7\left(\mathrm{CH}, \operatorname{Ar} \mathrm{C}_{5}\right), 116.7$ $\left.\left(\mathrm{CH}, \mathrm{ArC} \mathrm{C}_{3}\right), 55.0\left(\mathrm{CH}_{2}, \mathrm{ArCH}\right)_{2}\right), 38.5$ (bs, $\left.\mathrm{CH}_{3}, \mathrm{NMe}_{2}\right) .{ }^{1} \mathrm{H}$ ${ }^{15} \mathrm{~N} \mathrm{HMBC}\left(600.23 \mathrm{MHz} / 43.3 \mathrm{MHz}, \mathrm{CD}_{2} \mathrm{Cl}_{2}\right): \delta^{1} \mathrm{H} / \delta$ ${ }^{15} \mathrm{~N}(\mathrm{ppm})=4.23 /-179.6\left(\mathrm{ArCH}_{2} / \mathrm{N}\right.$ imino $), 4.23 /-$ $301.1\left(\mathrm{ArCH}_{2} / \mathrm{N}\right.$ amino).

\section{Synthesis of (E)-N'-(2-hydroxybenzyl)-N,N-} dimethylbenzamidinium bromide $\left[\mathrm{L}_{\mathbf{2}} \mathrm{H}_{2}\right][\mathrm{Br}]$ (white solid, $52 \mathrm{mg}, 79 \%$ ). $50 \mu \mathrm{l}$ of hydrobromic acid (48 wt. $\%$ in $\mathrm{H}_{2} \mathrm{O}$ ) were added to DCM solution ( $3 \mathrm{~mL}$ ) of $\mathbf{L 1 H}$ (50 mg, $0.2 \mathrm{mmol}$ ) cooled to $0{ }^{\circ} \mathrm{C}$ in an ice bath. The mixture was stirred for 30 minutes at room temperature, during which time a white precipitate was formed. The supernatant was removed by filtration and the residue was dried under vacuum to give the amidinium salt [ $\left.\mathbf{L 1 H}_{2}\right]$ [Br]. HRMS (ESI-pos): calcd for $\left[\mathrm{C}_{16} \mathrm{H}_{19} \mathrm{~N}_{2} \mathrm{O}-\mathrm{Br}\right]^{+}[\mathrm{M}]^{+}:$255.14919. Found: 255.14947 (1.1 ppm). Elemental Analysis: calcd for $\mathrm{C}_{16} \mathrm{H}_{19} \mathrm{BrN}_{2} \mathrm{O}: \mathrm{C}, 57.32 ; \mathrm{H}, 5.71 ; \mathrm{N}, 8.36 \%$. Found: $\mathrm{C}$, 57.51; H, 5.52; N, $7.99 \% .{ }^{1} \mathrm{H} \mathrm{NMR}\left(500 \mathrm{MHz}, \mathrm{CDCl}_{3}\right): \delta$ $(\mathrm{ppm})=9.50($ broad, $1 \mathrm{H}, \mathrm{NH}), 8.53($ broad, $1 \mathrm{H}, \mathrm{OH})$, $7.58(\mathrm{~m}, 1 \mathrm{H}, p-\mathrm{Ph}), 7.50(\mathrm{~m}, 2 \mathrm{H}, m-\mathrm{Ph}), 7.24(\mathrm{~m}, 2 \mathrm{H}, o-$
$\mathrm{Ph}), 7.16\left(\mathrm{dd},{ }^{3} J_{\mathrm{HH}}=8.1 \mathrm{~Hz},{ }^{4} J_{\mathrm{HH}}=1.2 \mathrm{~Hz}, 1 \mathrm{H}, \mathrm{Ar} \mathrm{H}_{3}\right.$ ), 7.04 (pseudo td, ${ }^{3} \mathrm{JHH}_{\mathrm{H}}=7.8 \mathrm{~Hz},{ }^{4} \mathrm{JHH}_{\mathrm{HH}}=1.7 \mathrm{~Hz}, 1 \mathrm{H}, \mathrm{Ar} \mathrm{H} \mathrm{H}_{4}$ ), 6.58 (pseudo td, ${ }^{3} \mathrm{HHH}_{\mathrm{HH}}=7.4 \mathrm{~Hz},{ }^{4} \mathrm{~J}_{\mathrm{HH}}=1.2 \mathrm{~Hz}, 1 \mathrm{H}, \mathrm{Ar} \mathrm{H} \mathrm{H}_{5}$ ), $\left.6.42\left(\mathrm{~d},{ }^{3}\right)_{\mathrm{HH}}=7.4 \mathrm{~Hz}, 1 \mathrm{H}, \operatorname{Ar~H} \mathrm{H}_{6}\right), 4.32\left(\mathrm{~d},{ }^{3} \mathrm{JHH}_{\mathrm{HH}}=4.8 \mathrm{~Hz}\right.$, $\left.2 \mathrm{H}, \mathrm{ArCH}_{2}\right), 3.48(\mathrm{~s}, 3 \mathrm{H}, \mathrm{NMe}), 2.91$ (s, 3H, NMe). ${ }^{13} \mathrm{C}\left\{{ }^{1} \mathrm{H}\right\}$ NMR $\left(126 \mathrm{MHz}, \mathrm{CDCl}_{3}\right): \delta(\mathrm{ppm})=165.1\left(\mathrm{C}_{\mathrm{q}}\right.$, $\mathrm{C}=\mathrm{N}), 155.3\left(\mathrm{C}_{\mathrm{q}}, \mathrm{C}-\mathrm{O}\right), 132.2(\mathrm{CH}, p-\mathrm{Ph}), 129.9(\mathrm{CH}, m-$ $\mathrm{Ph}), 129.7\left(\mathrm{CH}, \mathrm{ArC}_{4}\right), 129.4\left(\mathrm{CH}, \operatorname{ArC}_{6}\right) 127.7\left(\mathrm{CH}, o_{-}\right.$ $\mathrm{Ph}), 127.0\left(\mathrm{C}_{\mathrm{q}}, i-\mathrm{Ph}\right), 122.5\left(\mathrm{C}_{\mathrm{q}}, \mathrm{ArC}_{1}\right), 119.7\left(\mathrm{CH}, \mathrm{Ar} \mathrm{C}_{5}\right)$, $117.6\left(\mathrm{CH}, \mathrm{ArC} \mathrm{C}_{3}\right), 46.5\left(\mathrm{CH}_{2}, \mathrm{ArCH}\right), 42.6\left(\mathrm{CH}_{3}, \mathrm{NMe}\right)$, $41.0\left(\mathrm{CH}_{3}, \mathrm{NMe}\right) .{ }^{1} \mathrm{H}^{15} \mathrm{~N}$ HMBC $(600.23 \mathrm{MHz} / 43.3$ $\left.\mathrm{MHz}, \mathrm{CD}_{2} \mathrm{Cl}_{2}\right): \delta{ }^{1} \mathrm{H} / \delta^{15} \mathrm{~N}(\mathrm{ppm})=4.32 /-254.4\left(\mathrm{ArCH}_{2}\right.$ / $\mathrm{N}$ imino), 3.48 / -254.4 (NMe / $\mathrm{N}$ imino), 3.48 / 274.0 (NMe / N amino), $2.91 /-274.0$ (NMe / N amino).

Synthesis of L1Na (white solid, $0.83 \mathrm{~g}$, yield: $70 \%$ ). $N^{\prime}-$ (2-hydroxybenzyl)- $N, N$-dimethylbenzamidine L1H (1 equiv., $4.3 \mathrm{mmol}, 1.1 \mathrm{~g}$ ) and $\mathrm{NaH}$ (2 equiv., $95 \%$ purity, $8.6 \mathrm{mmol}, 208 \mathrm{mg}$ ) were suspended in THF $(20 \mathrm{~mL})$ and stirred $2 \mathrm{~h}$. Stirring was stopped and a resulting white salt was let to settle. The supernatant was cannulated with a borosilicate filter. The filtrate was concentrated to give a white solid which was washed with DCM $(2 \times 10 \mathrm{~mL})$ to give the product as a white solid. Elemental Analysis: calcd for $\mathrm{C}_{16} \mathrm{H}_{17} \mathrm{~N}_{2} \mathrm{NaO}$ : C, $69.55 ; H, 6.20 ; \mathrm{N}, 10.14 \%$. Found: $\mathrm{C}, 68.48 ; \mathrm{H}, 6.32 ; \mathrm{N}$, $10.24 \% .{ }^{1}$ H NMR $\left(500 \mathrm{MHz}\right.$, THF- $\left.\mathrm{d}_{8}\right): \delta(\mathrm{ppm})=7.44$ (m, 2H, $m$-Ph), $7.41(\mathrm{~m}, 1 \mathrm{H}, p$-Ph overlapping with $m$ $\mathrm{Ph}$ ), $7.04(\mathrm{~m}, 2 \mathrm{H}, \mathrm{o}-\mathrm{Ph}), 6.75$ (pseudo td, ${ }^{3} \mathrm{~J}_{\mathrm{HH}}=7.6 \mathrm{~Hz}$, $\left.\left.{ }^{4} J_{\mathrm{HH}}=2.0 \mathrm{~Hz}, 1 \mathrm{H}, \mathrm{Ar} \mathrm{H}\right)_{4}\right), 6.44\left(\mathrm{~d},{ }^{3} \mathrm{JHH}_{\mathrm{HH}}=8.0 \mathrm{~Hz}, 1 \mathrm{H}, \mathrm{Ar}\right.$ $\left.\mathrm{H}_{3}\right), 6.21\left(\mathrm{dd},{ }^{3} J_{\mathrm{HH}}=7.2 \mathrm{~Hz},{ }^{4} J_{\mathrm{HH}}=2.0 \mathrm{~Hz}, 1 \mathrm{H}, \mathrm{Ar} \mathrm{H}_{6}\right)$, 5.97 (pseudo t, ${ }^{3} \mathrm{~J}_{\mathrm{HH}}=7.1 \mathrm{~Hz}, 1 \mathrm{H}, \operatorname{Ar} \mathrm{H}_{5}$ ), $4.13(\mathrm{~s}, 2 \mathrm{H}$, $\left.\mathrm{ArCH}_{2}\right), 2.46\left(\mathrm{~s}, 6 \mathrm{H}, \mathrm{NMe}_{2}\right) .{ }^{13} \mathrm{C}\left\{{ }^{1} \mathrm{H}\right\}$ NMR $(126 \mathrm{MHz}$, THF- $\left.\mathrm{d}_{8}\right): \delta(p p m)=170.7\left(\mathrm{C}_{\mathrm{q}}, \mathrm{C}-\mathrm{O}\right), 163.4\left(\mathrm{C}_{\mathrm{q}}, \mathrm{C}=\mathrm{N}\right)$, $136.5\left(C_{q}, i-P h\right), 130.6\left(C_{q}, \operatorname{Ar} C_{1}\right), 130.4\left(C H, \operatorname{Ar} C_{6}\right)$, 129.2 ( $\mathrm{CH}, o-\mathrm{Ph}), 129.1$ ( $\mathrm{CH}, m-\mathrm{Ph}), 129.0(\mathrm{CH}, p-\mathrm{Ph})$, $128.5\left(\mathrm{CH}, \mathrm{Ar} \mathrm{C}_{4}\right), 119.8\left(\mathrm{CH}, \mathrm{Ar} \mathrm{C}_{3}\right), 110.7\left(\mathrm{CH}, \mathrm{ArC} \mathrm{C}_{5}\right)$, $54.7\left(\mathrm{CH}_{2}, \mathrm{ArCH}_{2}\right), 38.4\left(\mathrm{CH}_{3}, \mathrm{NMe}_{2}\right)$.

\section{Synthesis of (E)-N'-(2-} hydroxybenzyl)pyrrolidinylbenzamidine $\mathbf{L 2 H}$ (white powder, $2.45 \mathrm{~g}$, yield: $87 \%$ ). Same procedure than for L1H using pyrrolidinylchlorobenziminium chloride instead of $\mathrm{N}, \mathrm{N}$-dimethylchlorobenziminium chloride. HRMS (ESI-pos): calcd for $\left[\mathrm{C}_{18} \mathrm{H}_{21} \mathrm{~N}_{2} \mathrm{O}\right]^{+}[\mathrm{M}+\mathrm{H}]^{+}$: 281.16484. Found: 281.16277 (-1.9 ppm). Elemental Analysis: calcd for $\mathrm{C}_{18} \mathrm{H}_{20} \mathrm{~N}_{2} \mathrm{O}: \mathrm{C}, 77.11 ; \mathrm{H}, 7.19 ; \mathrm{N}, 9.99$ \%. Found: C, 76.94; H, 7.41; N, $9.88 \%$. ${ }^{1}$ H NMR (500 
$\left.\mathrm{MHz}, \mathrm{CDCl}_{3}\right), \delta$ (ppm): 11.81 (broad, $\left.1 \mathrm{H}, \mathrm{OH}\right), 7.50-$ $7.46(\mathrm{~m}, 3 \mathrm{H}, \mathrm{m}-\mathrm{Ph}$ and $p-\mathrm{Ph}), 7.19(\mathrm{~m}, 2 \mathrm{H}, \mathrm{o}-\mathrm{Ph}), 7.07$ $\left(\mathrm{m}, 1 \mathrm{H}, \mathrm{Ar} \mathrm{H}_{4}\right), 6.85\left(\mathrm{~d},{ }^{3} \mathrm{~J}_{\mathrm{H}-\mathrm{H}}=8.0 \mathrm{~Hz}, 1 \mathrm{H}, \mathrm{Ar} \mathrm{H}_{3}\right), 6.67-$ $6.61\left(\mathrm{~m}, 2 \mathrm{H}, \mathrm{Ar} \mathrm{H}_{5}\right.$ and $\left.\mathrm{Ar} \mathrm{H}_{6}\right), 4.33$ (s, 2H, $\left.\mathrm{ArCH}_{2}\right), 3.62$ (broad, $2 \mathrm{H}, \mathrm{NCH}_{2} \mathrm{CH}_{2}$ ), 3.03 (broad, $2 \mathrm{H}, \mathrm{NCH}_{2} \mathrm{CH}_{2}$ ), 1.97 (broad, $2 \mathrm{H}, \mathrm{NCH}_{2} \mathrm{CH}_{2}$ ), 1.82 (broad, $2 \mathrm{H}, \mathrm{NCH}_{2} \mathrm{CH}_{2}$ ). ${ }^{13} \mathrm{C}\left\{{ }^{1} \mathrm{H}\right\}$ NMR (126 MHz CDCl$), \delta(p p m): 160.3\left(\mathrm{C}_{\mathrm{q}}\right.$, $\mathrm{C}=\mathrm{N}), 158.5\left(\mathrm{C}_{\mathrm{q}}, \mathrm{C}-\mathrm{O}\right), 133.7\left(\mathrm{C}_{\mathrm{q}}, i-\mathrm{Ph}\right), 129.4(\mathrm{CH}, p-$ $\mathrm{Ph}), 129.2(\mathrm{CH}, m-\mathrm{Ph}), 127.8\left(\mathrm{CH}, \mathrm{ArC}_{4}\right), 127.4(\mathrm{CH}, \mathrm{Ar}$ $\left.\mathrm{C}_{6}\right), 127.2(\mathrm{CH}, o-\mathrm{Ph}), 125.1\left(\mathrm{C}_{\mathrm{q}}, \operatorname{Ar} \mathrm{C}_{1}\right), 118.6(\mathrm{CH}, \mathrm{Ar}$ $\left.\left.\mathrm{C}_{5}\right), 117.0\left(\mathrm{CH}, \operatorname{Ar} \mathrm{C}_{3}\right), 53.8\left(\mathrm{CH}_{2}, \operatorname{ArCH}\right)_{2}\right), 49.3\left(\mathrm{CH}_{2}\right.$, $\left.\mathrm{NCH}_{2} \mathrm{CH}_{2}\right), 46.9\left(\mathrm{CH}_{2}, \mathrm{NCH}_{2} \mathrm{CH}_{2}\right), 25.8\left(\mathrm{CH}_{2}, \mathrm{NCH}_{2} \mathrm{CH}_{2}\right)$, $24.9\left(\mathrm{CH}_{2}, \mathrm{NCH}_{2} \mathrm{CH}_{2}\right) .{ }^{1} \mathrm{H}^{15} \mathrm{~N}$ HMBC $(600.23 \mathrm{MHz} / 43.3$ $\left.\mathrm{MHz}, \mathrm{CDCl}_{3}, 250 \mathrm{~K}\right): \delta^{1} \mathrm{H} / \delta^{15} \mathrm{~N}(\mathrm{ppm})=4.33 /-194.4$ ( $\mathrm{ArCH}_{2} / \mathrm{N}$ imino), $1.96 /-274.1\left(\mathrm{NCH}_{2} \mathrm{CH}_{2} / \mathrm{N}\right.$ amino), 1.79 / -274.1 ( $\mathrm{NCH}_{2} \mathrm{CH}_{2} / \mathrm{N}$ amino).

\section{Synthesis of (E)-N'-(2-hydroxybenzyl)-N,N-} dimethylformamidine L3H (pale yellow solid, $0.642 \mathrm{~g}$, yield: $90 \%) . N, N$-Dimethylformamide dimethylacetal (1 equiv., 97 \% purity, $4.00 \mathrm{mmol}, 0.491 \mathrm{~g}$ ) in DCM (8 $\mathrm{mL}$ ) was added to 2-hydroxybenzylamine (1 equiv., $4.00 \mathrm{mmol}, 0.493 \mathrm{mg}$ ) in a microwave vial. The yellow solution was stirred $10 \mathrm{~min}$ under MW irradiation at $50{ }^{\circ} \mathrm{C}$. Volatiles were evaporated then DCM/pentane mixture $(25 \mathrm{~mL})$ was added. The brown solid was filtered and the solvent evaporated to afford the product L3H. HRMS (ESI-pos): calcd for $\left[\mathrm{C}_{10} \mathrm{H}_{15} \mathrm{~N}_{2} \mathrm{O}\right]^{+}$ $[\mathrm{M}+\mathrm{H}]^{+}:$179.11789. Found: $179.11699(-5.0 \mathrm{ppm})$. Elemental Analysis: calcd for $\mathrm{C}_{10} \mathrm{H}_{14} \mathrm{~N}_{2} \mathrm{O}: \mathrm{C}, 67.39 ; \mathrm{H}$, 7.92; N, $15.72 \%$. Found: $C, 67.55 ; H, 7.80 ; N, 15.55 \%$. ${ }^{1} \mathrm{H}$ NMR $\left(600 \mathrm{MHz}, \mathrm{CDCl}_{3}\right): \delta(\mathrm{ppm})=9.89$ (broad, $1 \mathrm{H}$, $\mathrm{OH}), 7.34$ (s, $1 \mathrm{H}, \mathrm{CH}$ formamidine), 7.11 (pseudo td, $\left.{ }^{3} J_{\mathrm{HH}}=7.8 \mathrm{~Hz},{ }^{4} J_{\mathrm{HH}}=1.7 \mathrm{~Hz}, 1 \mathrm{H}, \mathrm{Ar} \mathrm{H} \mathrm{H}_{4}\right), 6.95\left(\mathrm{dd},{ }^{3} \mathrm{JHH}_{\mathrm{HH}}=\right.$ $\left.7.5 \mathrm{~Hz},{ }^{4} J_{\mathrm{HH}} 1.6 \mathrm{~Hz}, 1 \mathrm{H}, \mathrm{Ar} \mathrm{H} \mathrm{H}_{6}\right), 6.84\left(\mathrm{dd},{ }^{3} J_{\mathrm{HH}}=8.1 \mathrm{~Hz}\right.$, ${ }^{4} J_{\mathrm{HH}}=1.2 \mathrm{~Hz}, 1 \mathrm{H}, \mathrm{Ar} \mathrm{H}_{3}$ ), 6.76 (pseudo td, ${ }^{3} J_{\mathrm{HH}}=7.4,{ }^{4} J_{\mathrm{HH}}$ $\left.=1.2 \mathrm{~Hz}, 1 \mathrm{H}, \operatorname{Ar} \mathrm{H}_{5}\right), 4.59\left(\mathrm{~s}, 2 \mathrm{H}, \mathrm{CH}_{2}\right), 2.88(\mathrm{~s}, 6 \mathrm{H}$, $\left.\mathrm{NMe}_{2}\right) .{ }^{13} \mathrm{C}\left\{{ }^{1} \mathrm{H}\right\}$ NMR $\left(\mathrm{CDCl}_{3}, 151 \mathrm{MHz}\right), \delta(\mathrm{ppm}): 157.7$ ( $\mathrm{Cq}, \operatorname{Ar} \mathrm{C}-\mathrm{O}), 154.6(\mathrm{Cq}, \mathrm{C}=\mathrm{N}), 127.9\left(\mathrm{CH}, \mathrm{Ar} \mathrm{C}_{4}\right), 127.0$ $\left(\mathrm{CH}, \mathrm{ArC}_{3}\right), 125.6\left(\mathrm{Cq}, \mathrm{ArC}_{1}\right), 118.9\left(\mathrm{CH}, \mathrm{Ar} \mathrm{C}_{5}\right), 116.8$ ( $\left.\mathrm{CH}, \mathrm{ArC} \mathrm{C}_{6}\right), 58.7\left(\mathrm{CH}_{2}, \mathrm{ArCH}_{2}\right), 40.1$ (broad, $\mathrm{CH}_{3}, \mathrm{NMe}_{2}$ ), 34.7 (broad, $\left.\mathrm{CH}_{3}, \mathrm{NMe}_{2}\right)$. HMBC $(600.23 \mathrm{MHz} / 43.3$ $\left.\mathrm{MHz}, \mathrm{CDCl}_{3}\right): \delta^{1} \mathrm{H} / \delta^{15} \mathrm{~N}(\mathrm{ppm})=7.32 /-185.3(\mathrm{HC}=\mathrm{N}$ / $\mathrm{N}$ imino), 7.32 / -307.7 ( $H \mathrm{C}=\mathrm{N} / \mathrm{N}$ amino), 4.59 / $185.3\left(\mathrm{ArCH}_{2} / \mathrm{N}\right.$ imino), 2.88 / -307.7 ( $\mathrm{NCH}_{3} / \mathrm{N}$ imino).

\section{Synthesis of (E)-N'-(2-hydroxybenzyl)-N,N-} dimethylacetamidine $\mathbf{L} \mathbf{4 H}$ (pale yellow solid, $0.650 \mathrm{~g}$, yield: $85 \%$ ). Same procedure than for $\mathrm{L} 3 \mathrm{H}$ using $\mathrm{N}, \mathrm{N}$ -
Dimethylacetamide dimethylacetal instead of $\mathrm{N}, \mathrm{N}$ Dimethylformamide dimethylacetal. HR-MS (ESI-pos): calcd for $\left[\mathrm{C}_{11} \mathrm{H}_{17} \mathrm{~N}_{2} \mathrm{O}\right]^{+}[\mathrm{M}+\mathrm{H}]^{+}:$193.13354. Found: 193.13303 (-2.6 ppm). Elemental Analysis: calcd for $\mathrm{C}_{11} \mathrm{H}_{16} \mathrm{~N}_{2} \mathrm{O}: \mathrm{C}, 68.72 ; \mathrm{H}, 8.39 ; \mathrm{N}, 14.57$ \%. Found: $\mathrm{C}$, 68.56; $\mathrm{H}, 8.79 ; \mathrm{N}, 14.53 \% .{ }^{1} \mathrm{H}$ NMR $\left(500 \mathrm{MHz}, \mathrm{CD}_{2} \mathrm{Cl}_{2}\right)$ : $\delta(\mathrm{ppm})=11.47($ broad, $1 \mathrm{H}, \mathrm{OH}), 7.05\left(\mathrm{~m}, 1 \mathrm{H}, \mathrm{H}_{4}\right), 6.96$ $\left(\mathrm{m}, 1 \mathrm{H}, \mathrm{H}_{3}\right), 6.73-6.69\left(\mathrm{~m}, 2 \mathrm{H}, \mathrm{H}_{5}\right.$ and $\left.\mathrm{H}_{6}\right), 4.58(\mathrm{~s}, 2 \mathrm{H}$, $\left.\mathrm{CH}_{2}\right), 2.95\left(\mathrm{~s}, 6 \mathrm{H}, \mathrm{NMe}_{2}\right), 2.00$ (s, 3H, $\mathrm{CH}_{3}$ acetamidine). ${ }^{13} \mathrm{C}\left\{{ }^{1} \mathrm{H}\right\}$ NMR (151 MHz, $\left.\mathrm{CD}_{2} \mathrm{Cl}_{2}\right), \delta$ (ppm): 160.0 (Cq, Ar $\mathrm{C}-\mathrm{O}), 158.9$ ( $\mathrm{Cq}, \mathrm{C}=\mathrm{N}), 127.3\left(\mathrm{CH}, \mathrm{Ar}_{3}\right.$ overlapping with $\left.\operatorname{ArC}_{4}\right), 124.3\left(\mathrm{Cq}, \mathrm{ArC}_{1}\right), 118.1\left(\mathrm{CH}, \mathrm{ArC}_{5 / 6}\right), 116.5$ $\left(\mathrm{CH}, \mathrm{ArC} \mathrm{C}_{5 / 6}\right), 53.6\left(\mathrm{CH}_{2}, \mathrm{ArCH}\right), 38.2\left(\mathrm{CH}_{3}, \mathrm{NMe}_{2}\right), 12.6$ $\left(\mathrm{CH}_{3}\right.$, acetamidine). HMBC $(600.23 \mathrm{MHz} / 43.3 \mathrm{MHz}$, $\left.\mathrm{CDCl}_{3}\right): \delta{ }^{1} \mathrm{H} / \delta^{15} \mathrm{~N}(\mathrm{ppm})=4.58 /-183.1\left(\mathrm{ArCH}_{2} / \mathrm{N}\right.$ imino), 2.95 / -299.4 (NMe / N amino), 1.99 / -183.1 (acetamidine / N imino), 1.99 / -299.4 (acetamidine / $\mathrm{N}$ amino).

Synthesis of 1a (orange crystals, $230 \mathrm{mg}$, yield: $66 \%$ ). THF solution ( $20 \mathrm{~mL}$ ) of $\mathbf{L 1 H}$ (1 equiv., $1.00 \mathrm{mmol}, 254$ $\mathrm{mg}$ ) was slowly added to a Schlenk flask containing a diethylzinc solution (1 equiv., $1 \mathrm{M}$ in hexanes, 1.00 $\mathrm{mmol}, 1.00 \mathrm{~mL}$ ). The mixture was stirred for $2 \mathrm{~h}$ at $\mathrm{rt}$. The volatiles were evaporated. The residual solid was recrystallized by layering technique using a DCM/pentane system. After several days, the complex 1a was obtained as orange crystals ( $230 \mathrm{mg}, 66 \%$ ). Elemental Analysis: calcd for $\mathrm{C}_{36} \mathrm{H}_{44} \mathrm{~N}_{4} \mathrm{O}_{2} \mathrm{Zn}_{2}$ : $\mathrm{C}, 62.17$; $H, 6.38 ; \mathrm{N}, 8.06 \%$. Found: $C, 61.95 ; H, 6.46 ; \mathrm{N}, 7.97 \%$. ${ }^{1} \mathrm{H}$ NMR $\left(500 \mathrm{MHz}, \mathrm{THF}-\mathrm{d}_{8}\right): \delta(\mathrm{ppm})=7.51$ (broad, $4 \mathrm{H}$, $m$-Ph), 7.49 (broad, $2 \mathrm{H}, p$-Ph overlapping with $m-\mathrm{Ph}$ ), 7.13 (broad, $4 \mathrm{H}, o-\mathrm{Ph}$ ), 6.95 (pseudo t, ${ }^{3} J_{\mathrm{HH}}=7.7 \mathrm{~Hz}$, $\left.2 \mathrm{H}, \operatorname{Ar~} \mathrm{H}_{4}\right), 6.69\left(\mathrm{~d}, 3_{\mathrm{HH}}=8.0 \mathrm{~Hz}, 2 \mathrm{H}, \mathrm{Ar} \mathrm{H} \mathrm{H}_{3}\right), 6.40$ (pseudo t, $\left.{ }^{3} \mathrm{~J}_{\mathrm{HH}}=7.3 \mathrm{~Hz}, 2 \mathrm{H}, \mathrm{Ar} \mathrm{H} \mathrm{H}_{5}\right), 6.28\left(\mathrm{~d},{ }^{3} J_{\mathrm{HH}}=7.3\right.$ $\mathrm{Hz}, 2 \mathrm{H}, \mathrm{Ar} \mathrm{H}_{6}$ ), 4.13 (broad, 4H, $\mathrm{ArCH}_{2}$ ), 2.95 (broad, $\left.12 \mathrm{H}, \mathrm{NMe}_{2}\right), 1.04\left(\mathrm{t},{ }^{3} \mathrm{~J}_{\mathrm{HH}}=8.1 \mathrm{~Hz}, 6 \mathrm{H}, \mathrm{CH}_{2} \mathrm{CH}_{3}\right), 0.01$ (q, $\left.{ }^{3} J_{\mathrm{HH}}=8.1 \mathrm{~Hz}, 4 \mathrm{H}, \mathrm{CH}_{2} \mathrm{CH}_{3}\right) \cdot{ }^{13} \mathrm{C}\left\{{ }^{1} \mathrm{H}\right\}$ NMR (THF-d 8,126 $\mathrm{MHz},): \delta(\mathrm{ppm})=168.9\left(\mathrm{C}_{q}, \mathrm{C}=\mathrm{N}\right), 164.5\left(\mathrm{C}_{q}, \mathrm{C}-\mathrm{O}\right)$, $134.5\left(\mathrm{C}_{q}, i-\mathrm{Ph}\right), 130.5(\mathrm{CH}, p-\mathrm{Ph}), 130.1\left(\mathrm{C}_{\mathrm{q}}, \mathrm{Ar}_{\mathrm{C}}\right)$, 129.5 (2 overlapping $\mathrm{CH}, m$-Ph and $\left.\mathrm{Ar}_{6}\right), 129.3(\mathrm{CH}$, o-Ph), $129.0\left(\mathrm{CH}, \operatorname{ArC}_{4}\right), 120.2\left(\mathrm{CH}, \operatorname{ArC}_{3}\right), 116.4(\mathrm{CH}$, $\left.\left.\operatorname{ArC} \mathrm{C}_{5}\right), 55.0\left(\mathrm{CH}_{2}, \mathrm{ArCH}\right)_{2}\right), 40.2\left(\mathrm{CH}_{3}, \mathrm{NMe}_{2}\right), 13.3\left(\mathrm{CH}_{3}\right.$, $\mathrm{ZnEt}), 0.5\left(\mathrm{CH}_{2}, \mathrm{ZnEt}\right)$.

Synthesis of 2a (white crystals, $108 \mathrm{mg}$, yield: $44 \%$ ). Diethylzinc solution ( $1 \mathrm{M}$ in hexanes, $0.655 \mathrm{~mL}, 0.656$ mmol, 1equiv.) was slowly added into DCM solution of L2H (183.8 mg, 0.656 mmol, 1equiv.). The mixture was 
stirred $2 \mathrm{~h}$ at room temperature. The volatiles were evaporated and the residual solid was purified by recrystallization using a DCM/diethyl ether biphasic system. Elemental analysis: calcd for $\mathrm{C}_{40} \mathrm{H}_{48} \mathrm{~N}_{4} \mathrm{O}_{2} \mathrm{Zn}_{2}$ : C, 64.25; H, 6.47; N, 7.49 \%. Found: C, 62.45; H, 6.84; $\mathrm{N}, 7.54 \% .{ }^{1} \mathrm{H}$ NMR (500 MHz, $\mathrm{CD}_{2} \mathrm{Cl}_{2}$ ), $\delta$ (ppm): 7.50 (broad, 6H, Ph), 7.09 (broad, 4H, Ph), 7.04 (pseudo t, ${ }^{3} \mathrm{~J}_{\mathrm{H}-\mathrm{H}}=7.8 \mathrm{~Hz}, 2 \mathrm{H}, \mathrm{Ar} \mathrm{H} \mathrm{H}_{4}$ overlapping Ph), $6.67\left(\mathrm{~d},{ }^{3} \mathrm{~J}_{\mathrm{H}-\mathrm{H}}=\right.$ $7.9 \mathrm{~Hz}, 2 \mathrm{H}, \mathrm{Ar} \mathrm{H}_{3}$ ), 6.47 (pseudo t, ${ }^{3} \mathrm{~J}_{\mathrm{H}-\mathrm{H}}=7.3 \mathrm{~Hz}, 2 \mathrm{H}, \mathrm{Ar}$ $\left.\mathrm{H}_{5}\right), 6.30\left(\mathrm{~d},{ }^{3} \mathrm{~J}_{\mathrm{H}-\mathrm{H}}=7.3 \mathrm{~Hz}, 2 \mathrm{H}, \mathrm{Ar} \mathrm{H}_{6}\right), 4.12$ (broad, $4 \mathrm{H}$, $\mathrm{ArCH}_{2}$ ), 3.35 (broad, $8 \mathrm{H}, \mathrm{NCH}_{2} \mathrm{CH}_{2}$ ), 1.80 (broad, $8 \mathrm{H}$, $\mathrm{NCH}_{2} \mathrm{CH}_{2}$ ), 1.07 (broad, 6H, $\mathrm{CH}_{2} \mathrm{CH}_{3}$ ), 0.00 (broad, $4 \mathrm{H}$, $\left.\mathrm{CH}_{2} \mathrm{CH}_{3}\right) .{ }^{13} \mathrm{C}\left\{{ }^{1} \mathrm{H}\right\}$ NMR (126 MHz, $\left.\mathrm{CD}_{2} \mathrm{Cl}_{2}\right), \delta$ (ppm): $164.9\left(C_{q}, C=N\right), 164.1\left(C_{q}, C-O\right), 135.1\left(C_{q}, i-P h\right), 129.8$ $\left(\mathrm{C}_{q}, \operatorname{Ar} \mathrm{C}_{1}\right), 129.7\left(\mathrm{CH}, \mathrm{Ar} \mathrm{C}_{6}\right), 129.3$ (2 overlapping $\mathrm{CH}$, $\mathrm{Ph}), 128.8\left(\mathrm{CH}, \mathrm{ArC}_{4}\right), 127.9(\mathrm{CH}, \mathrm{Ph}), 119.9\left(\mathrm{CH}, \mathrm{ArC}_{3}\right)$, $\left.116.1\left(\mathrm{CH}, \operatorname{Ar} \mathrm{C}_{5}\right), 53.9\left(\mathrm{CH}_{2}, \operatorname{ArCH}\right)_{2}\right), 49.8\left(\mathrm{CH}_{2}\right.$, $\left.\mathrm{NCH}_{2} \mathrm{CH}_{2}\right), 25.6\left(\mathrm{CH}_{2}, \mathrm{NCH}_{2} \mathrm{CH}_{2}\right), 13.2\left(\mathrm{CH}_{3}, \mathrm{ZnEt}\right), 0.6$ $\left(\mathrm{CH}_{2}, \mathrm{ZnEt}\right)$.

Synthesis of 3a (white solid, $340 \mathrm{mg}$, yield: 83 \%). L3H (1 equiv., $1.50 \mathrm{mmol}, 267 \mathrm{mg}$ ) was dissolved in DCM (15 mL), and added to diethylzinc solution (1 equiv., 1 $M$ in hexanes, $1.50 \mathrm{mmol}, 1.50 \mathrm{~mL}$ ). The mixture was stirred $2 \mathrm{~h}$ at $\mathrm{rt}$. The volatiles were evaporated, and the residual solid was washed with pentane $(2 \times 5 \mathrm{~mL})$ to give 3a. Elemental Analysis: calcd for $\mathrm{C}_{24} \mathrm{H}_{36} \mathrm{~N}_{4} \mathrm{O}_{2} \mathrm{Zn}_{2}$ : C, 53.05; $\mathrm{H}, 6.68 ; \mathrm{N}, 10.31 \%$. Found: $\mathrm{C}$, 52.66; $\mathrm{H}, 6.75 ; \mathrm{N}, 10.02 \%$. ${ }^{1} \mathrm{H}$ NMR (500 MHz, $\left.\mathrm{CD}_{2} \mathrm{Cl}_{2}\right)$ : $\delta(\mathrm{ppm})=7.49(\mathrm{~s}, 2 \mathrm{H}, \mathrm{CH}$ formamidine), 7.06 (pseudo $\left.\mathrm{td},{ }^{3} J_{\mathrm{HH}}=7.7 \mathrm{~Hz},{ }^{4} J_{\mathrm{HH}}=1.9 \mathrm{~Hz}, 2 \mathrm{H}, \mathrm{Ar} \mathrm{H}_{4}\right), 6.98\left(\mathrm{dd},{ }^{3} J_{\mathrm{HH}}\right.$ $\left.=7.3 \mathrm{~Hz},{ }^{4} J_{\mathrm{HH}}=1.8 \mathrm{~Hz}, 2 \mathrm{H}, \mathrm{Ar} \mathrm{H} \mathrm{H}_{6}\right), 6.65\left(\mathrm{~d},{ }^{3} J_{\mathrm{HH}}=8.0 \mathrm{~Hz}\right.$, $2 \mathrm{H}, \mathrm{Ar} \mathrm{H}_{3}$ ), 6.60 (pseudo t, ${ }^{3} \mathrm{JHH}_{\mathrm{HH}}=7.2 \mathrm{~Hz}, 2 \mathrm{H}, \mathrm{Ar} \mathrm{H}_{5}$ ), 4.45 (broad, $\left.4 \mathrm{H}, \mathrm{ArCH}_{2}\right), 3.05\left(\mathrm{~s}, 12 \mathrm{H}, \mathrm{NMe}_{2}\right), 0.87\left(\mathrm{t},{ }^{3} \mathrm{HH}_{\mathrm{HH}}=\right.$ $\left.8.1 \mathrm{~Hz}, 6 \mathrm{H}, \mathrm{CH}_{2} \mathrm{CH}_{3}\right),-0.16\left(\mathrm{q}, 3^{3} \mathrm{HH}_{\mathrm{H}}=8.0 \mathrm{~Hz}, 4 \mathrm{H}\right.$, $\left.\mathrm{CH}_{2} \mathrm{CH}_{3}\right) \cdot{ }^{13} \mathrm{C}\left\{{ }^{1} \mathrm{H}\right\}$ NMR $\left(126 \mathrm{MHz}, \mathrm{CD}_{2} \mathrm{Cl}_{2}\right): \delta(\mathrm{ppm})=$ $163.6\left(C_{q}, \operatorname{Ar} C-O\right), 158.5\left(C_{q}, C=N\right), 129.8\left(C_{q}, \operatorname{Ar} C_{1}\right)$, $129.2\left(\mathrm{CH}, \mathrm{ArC}_{4}\right), 128.8\left(\mathrm{CH}, \mathrm{ArC}_{6}\right), 120.1\left(\mathrm{CH}, \mathrm{Ar} \mathrm{C}_{3}\right)$, $116.7\left(\mathrm{CH}, \mathrm{ArC}_{5}\right), 59.8\left(\mathrm{CH}_{2}\right), 39.1$ (bs, $\left.\mathrm{CH}_{3}, \mathrm{NMe}_{2}\right), 12.8$ $\left(\mathrm{CH}_{3}, \mathrm{ZnEt}\right), 0.1\left(\mathrm{CH}_{2}, \mathrm{ZnEt}\right)$.

Synthesis of 4a (white solid, $366 \mathrm{mg}$, yield: $86 \%$ ). L4H (1 equiv., $1.50 \mathrm{mmol}, 288 \mathrm{mg}$ ) was dissolved in DCM (15 mL), and added to diethylzinc solution (1 equiv., 1 $\mathrm{M}$ in hexane, $1.50 \mathrm{mmol}, 1.50 \mathrm{~mL}$ ). The mixture was stirred $2 \mathrm{~h}$ at $\mathrm{rt}$. The volatiles were evaporated, and the residual solid was washed with pentane $(2 \times 5 \mathrm{~mL})$ to give 4a as a white solid. Elemental Analysis: calcd for $\mathrm{C}_{26} \mathrm{H}_{40} \mathrm{~N}_{4} \mathrm{O}_{2} \mathrm{Zn}_{2}: \mathrm{C}, 54.65 ; \mathrm{H}, 7.06 ; \mathrm{N}, 9.81 \%$. Found:
C, 54.57; H, 7.16; N, $9.71 \% .{ }^{1} \mathrm{H}$ NMR $(500 \mathrm{MHz}$, $\mathrm{CD}_{2} \mathrm{Cl}_{2}$ ): $\delta(\mathrm{ppm})=7.04$ (pseudo $\mathrm{t}^{3} \mathrm{~J}_{\mathrm{HH}}=8.3 \mathrm{~Hz}, 2 \mathrm{H}, \mathrm{Ar}$ $\left.\mathrm{H}_{4}\right), 7.02\left(\mathrm{~d},{ }^{3} \mathrm{~J}_{\mathrm{HH}}=8.3 \mathrm{~Hz}, 2 \mathrm{H}, \mathrm{Ar} \mathrm{H} \mathrm{H}_{6}\right.$ overlapping with $\left.\mathrm{Ar} \mathrm{H} \mathrm{H}_{4}\right), 6.64\left(\mathrm{~d},{ }^{3} \mathrm{H}_{\mathrm{HH}}=8.0 \mathrm{~Hz}, 2 \mathrm{H}, \mathrm{Ar} \mathrm{H}_{3}\right.$ ), 6.59 (pseudo $\left.\mathrm{t},{ }^{3} J_{\mathrm{HH}}=7.3 \mathrm{~Hz}, 2 \mathrm{H}, \mathrm{Ar} \mathrm{H} \mathrm{H}_{5}\right), 4.39\left(\mathrm{~s}, 4 \mathrm{H}, \mathrm{ArCH}_{2}\right), 3.08(\mathrm{~s}$, $\left.12 \mathrm{H}, \mathrm{NMe}_{2}\right), 2.08\left(\mathrm{~s}, 6 \mathrm{H}, \mathrm{CH}_{3}\right.$ acetamidine), $0.90\left(\mathrm{t}^{3}{ }^{3} \mathrm{HH}_{\mathrm{H}}\right.$ $\left.=8.3 \mathrm{~Hz}, 6 \mathrm{H}, \mathrm{CH}_{2} \mathrm{CH}_{3}\right),-0.16\left(\mathrm{q},{ }^{3} \mathrm{~J}_{\mathrm{HH}}=8.3 \mathrm{~Hz}, 4 \mathrm{H}, \mathrm{CH}_{2}\right.$ $\left.\mathrm{CH}_{2} \mathrm{CH}_{3}\right) \cdot{ }^{13} \mathrm{C}\left\{{ }^{1} \mathrm{H}\right\}$ NMR $\left(126 \mathrm{MHz}, \mathrm{CD}_{2} \mathrm{Cl}_{2}\right): \delta(\mathrm{ppm})=$ $166.9\left(C_{q}, C=N\right), 163.9\left(C_{q}, \operatorname{ArC}-0\right), 129.7\left(C_{q}, \operatorname{Ar} C_{1}\right)$, $129.3\left(\mathrm{CH}, \mathrm{ArC}_{4 / 6}\right), 128.9\left(\mathrm{CH}, \mathrm{ArC}_{4 / 6}\right), 120.1(\mathrm{CH}, \mathrm{Ar}$ $\left.\left.\mathrm{C}_{3}\right), 116.3\left(\mathrm{CH}, \operatorname{Ar} \mathrm{C}_{5}\right), 52.9\left(\mathrm{CH}_{2}, \operatorname{ArCH}\right)_{2}\right), 40.0\left(\mathrm{CH}_{3}\right.$, $\left.\mathrm{NMe}_{2}\right), 15.5\left(\mathrm{CH}_{3}\right.$, acetamidine $), 12.9\left(\mathrm{CH}_{3}, \mathrm{ZnEt}\right),-0.4$ ( $\left.\mathrm{CH}_{2}, \mathrm{ZnEt}\right)$.

Synthesis of 1a' (white crystals, $75 \mathrm{mg}$, yield: $35 \%$ ). $\mathrm{ZnCl}_{2}$ (1 equiv., $0.375 \mathrm{mmol}, 53 \mathrm{mg}$ ) was suspended in THF $(7.5 \mathrm{~mL})$ and cooled to $-80^{\circ} \mathrm{C}$. In another Schlenk flask, phenate L1Na ( 2 equiv., $0.750 \mathrm{mmol}, 207 \mathrm{mg}$ ) was solubilized in THF (15 mL), cooled to $-80^{\circ} \mathrm{C}$ and slowly added to $\mathrm{ZnCl}_{2}$. After addition, the $-80^{\circ} \mathrm{C}$ bath was removed and the mixture stirred for $1 \mathrm{~h}$ at $\mathrm{rt}$. Stirring was stopped and a resulting white salt was let to settle. The supernatant was cannulated with a borosilicate filter. The filtrate was concentrated to give the crude product as a white foam. It was further purified by vapor diffusion recrystallization using a toluene/pentane system to give the 1a'. HRMS (ESIpos): calcd for $\left[\mathrm{C}_{32} \mathrm{H}_{35} \mathrm{~N}_{4} \mathrm{O}_{2} \mathrm{Zn}\right]^{+}\left[\mathrm{M}+\mathrm{H}^{+}\right.$: 571.20460 . Found: 571.20325 (-2.4 ppm). Elemental Analysis: calcd for $\mathrm{C}_{32} \mathrm{H}_{34} \mathrm{~N}_{4} \mathrm{O}_{2} \mathrm{Zn}: \mathrm{C}, 67.19 ; \mathrm{H}, 5.99 ; \mathrm{N}, 9.79 \%$. Found: $\mathrm{C}, 66.32 ; \mathrm{H}, 5.68 ; \mathrm{N}, 9.46 \%$. ${ }^{1} \mathrm{H}$ NMR $(300 \mathrm{MHz}$, $\left.\mathrm{CD}_{2} \mathrm{Cl}_{2}\right): \delta(\mathrm{ppm})=7.61-7.50(\mathrm{~m}, 4 \mathrm{H}+2 \mathrm{H}, m-\mathrm{Ph}$ and $p-$ $\mathrm{Ph}$ ), $7.36(\mathrm{~m}, 2 \mathrm{H}, \mathrm{o}-\mathrm{Ph}), 7.06$ (m, 2H, o-Ph), 7.01 (ddd, $\left.{ }^{3} J_{\mathrm{HH}}=8.1,6.6 \mathrm{~Hz},{ }^{4} J_{\mathrm{HH}}=2.5 \mathrm{~Hz}, 2 \mathrm{H}, \mathrm{Ar} \mathrm{H}_{4}\right), 6.62\left(\mathrm{dd},{ }^{3} \mathrm{H}_{\mathrm{HH}}\right.$ $\left.=8.0 \mathrm{~Hz},{ }^{4} J_{\mathrm{HH}}=1.1 \mathrm{~Hz}, 2 \mathrm{H}, \mathrm{Ar} \mathrm{H}\right)_{3}, 6.33-6.27(\mathrm{~m}, 2 \mathrm{H}+$ $2 \mathrm{H}, \mathrm{Ar} \mathrm{H}_{6}$ and $\left.\mathrm{Ar} \mathrm{H}_{5}\right), 4.31\left(\mathrm{~d},{ }^{2} \mathrm{~J}_{\mathrm{HH}}=13.4 \mathrm{~Hz}, 2 \mathrm{H}, \mathrm{ArCH}_{2}\right.$ AB spin system), $3.91\left(\mathrm{~d},{ }^{2} \mathrm{~J}_{\mathrm{HH}}=13.4 \mathrm{~Hz}, 2 \mathrm{H}, \mathrm{ArCH}_{2} \mathrm{AB}\right.$ spin system), $2.84\left(\mathrm{~s}, 12 \mathrm{H}, \mathrm{NMe}_{2}\right) \cdot{ }^{13} \mathrm{C}\left\{{ }^{1} \mathrm{H}\right\}$ NMR (126 $\left.\mathrm{MHz}, \mathrm{CD}_{2} \mathrm{Cl}_{2}\right): \delta(\mathrm{ppm})=169.2\left(\mathrm{C}_{q}, \mathrm{C}=\mathrm{N}\right), 167.5\left(\mathrm{C}_{q}, \mathrm{Ar}\right.$ C-O), $133.4\left(\mathrm{C}_{q}, i-\mathrm{Ph}\right), 130.7(\mathrm{CH}, p-\mathrm{Ph}), 129.7(\mathrm{CH}, m-$ $\mathrm{Ph}, 129.5\left(\mathrm{CH}, \mathrm{Ar} \mathrm{C}_{4}\right), 129.4\left(\mathrm{CH}, \mathrm{Ar} \mathrm{C}_{6}\right), 129.3(\mathrm{CH}, m-$ $\mathrm{Ph}), 129.1$ ( $\mathrm{CH}, o-\mathrm{Ph}), 128.4(\mathrm{CH}, o-\mathrm{Ph}), 127.6\left(\mathrm{C}_{\mathrm{q}}, \mathrm{Ar}\right.$ $\left.\mathrm{C}_{1}\right), 119.6\left(\mathrm{CH}, \operatorname{Ar} \mathrm{C}_{3}\right), 113.6\left(\mathrm{CH}, \operatorname{Ar} \mathrm{C}_{5}\right), 55.7\left(\mathrm{CH}_{2}\right.$, $\left.\mathrm{ArCH} \mathrm{H}_{2}\right), 40.1\left(\mathrm{CH}_{3}, \mathrm{NMe}_{2}\right)$.

Synthesis of $\mathbf{1 b}$ (yellow powder, $240 \mathrm{mg}$, yield: 77\%). THF solution ( $20 \mathrm{~mL}$ ) of L1H (1 equiv., $1.00 \mathrm{mmol}, 254$ $\mathrm{mg}$ ) was slowly added to a Schlenk flask containing trimethylaluminium solution (1 equiv., $2 \mathrm{M}$ in 
hexanes, $1.00 \mathrm{mmol}, 0.500 \mathrm{~mL}$ ). The mixture was stirred $2 \mathrm{~h}$ at $\mathrm{rt}$. The volatiles were evaporated, and the residual solid was washed with pentane $(3 \times 10$ $\mathrm{mL}$ ) to give $\mathbf{1} \mathbf{b}$. Suitable crystal of $\mathbf{1} \mathbf{b}$ for $X$-ray diffraction was obtained by vapor diffusion using a DCM/pentane system. HRMS (ESI-pos): calcd for $\left[\mathrm{C}_{17} \mathrm{H}_{20} \mathrm{AlN}_{2} \mathrm{O}\right]^{+}\left[\mathrm{M}-\mathrm{CH}_{3}\right]^{+}:$295.13855. Found: 295.13889 (-1.1 ppm). Elemental Analysis: calcd for $\mathrm{C}_{18} \mathrm{H}_{23} \mathrm{AlN}_{2} \mathrm{O}: \mathrm{C}, 69.66 ; \mathrm{H}, 7.47 ; \mathrm{N}, 9.03 \%$. Found: $\mathrm{C}$, 69.71; H, 7.58; N, $9.37 \%$. ${ }^{1}$ H NMR (500 MHz, THF-d 8 ): $\delta(\mathrm{ppm})=7.57(\mathrm{~m}, 1 \mathrm{H}, \mathrm{p}-\mathrm{Ph}), 7.45(\mathrm{~m}, 2 \mathrm{H}, \mathrm{m}-\mathrm{Ph}), 7.11$ $\left(\mathrm{m}, 2 \mathrm{H}, \mathrm{o}-\mathrm{Ph}\right.$ ), 6.96 (pseudo td, ${ }^{3} J_{\mathrm{HH}}=7.8 \mathrm{~Hz},{ }^{4} J_{\mathrm{HH}}=1.8$ $\left.\mathrm{Hz}, 1 \mathrm{H}, \mathrm{Ar} \mathrm{H}_{4}\right), 6.60\left(\mathrm{dd},{ }^{3} \mathrm{~J}_{\mathrm{HH}}=7.9 \mathrm{~Hz},{ }^{4} \mathrm{~J}_{\mathrm{HH}}=1.2 \mathrm{~Hz}, 1 \mathrm{H}\right.$, Ar $\mathrm{H}_{3}$ ), 6.34 (pseudo td, ${ }^{3} \mathrm{~J}_{\mathrm{HH}}=7.4 \mathrm{~Hz},{ }^{4} \mathrm{~J}_{\mathrm{HH}}=1.2 \mathrm{~Hz}, 1 \mathrm{H}$, Ar $\left.\mathrm{H}_{5}\right), 6.05\left(\mathrm{dd},{ }^{3} J_{\mathrm{HH}}=7.4 \mathrm{~Hz},{ }^{4} \mathrm{~J}_{\mathrm{HH}}=1.8 \mathrm{~Hz}, 1 \mathrm{H}, \mathrm{Ar} \mathrm{H}_{6}\right)$, $3.93\left(\mathrm{~s}, 2 \mathrm{H}, \mathrm{ArCH}_{2}\right), 3.03\left(\mathrm{~s}, 6 \mathrm{H}, \mathrm{NMe}_{2}\right),-0.80(\mathrm{~s}, 6 \mathrm{H}$, AlMe $).{ }^{13} \mathrm{C}\left\{{ }^{1} \mathrm{H}\right\}$ NMR (126 MHz, THF-d 8 ): $\delta(\mathrm{ppm})=$ $173.3\left(C_{q}, C=N\right), 162.0\left(C_{q}, \operatorname{Ar} C-O\right), 132.9\left(C_{q}, i-P h\right)$, $131.8(\mathrm{CH}, p-\mathrm{Ph}), 129.7(\mathrm{CH}, m-\mathrm{Ph}), 129.6(\mathrm{CH}, o-\mathrm{Ph})$, 129.4 ( $\left.\mathrm{CH}, \mathrm{ArC}_{4}\right), 128.8\left(\mathrm{C}_{9}, \operatorname{ArC}_{1}\right), 127.9\left(\mathrm{CH}, \operatorname{ArC}_{6}\right)$, $119.2\left(\mathrm{CH}, \mathrm{ArC}_{3}\right), 116.1(\mathrm{CH}, \operatorname{ArC})_{5}, 53.6\left(\mathrm{CH}_{2}, \mathrm{ArCH}_{2}\right)$, $41.5\left(\mathrm{CH}_{3}, \mathrm{NMe}_{2}\right),-8.9$ (broad, $\left.\mathrm{CH}_{3}, \mathrm{AlMe}_{2}\right)$.

Synthesis of $\mathbf{2 b}$ (white powder, $119 \mathrm{mg}$, yield: $75 \%$ ). Same procedure than for $\mathbf{1 b}$. Elemental analysis: calcd for [ $\left.\mathrm{C}_{20} \mathrm{H}_{25} \mathrm{AlN}_{2} \mathrm{O}\right]: \mathrm{C}, 71.41 ; \mathrm{H}, 7.49 ; \mathrm{N}, 8.33 \%$. Found: $\mathrm{C}, 70.60 ; \mathrm{H}, 7.41 ; \mathrm{N}, 7.80 \%$. ${ }^{1} \mathrm{H}$ NMR $(600 \mathrm{MHz}$, $\left.\mathrm{CD}_{2} \mathrm{Cl}_{2}\right), \delta(\mathrm{ppm}): 7.56(\mathrm{~m}, 1 \mathrm{H}, p-\mathrm{Ph}), 7.49(\mathrm{~m}, 2 \mathrm{H}, \mathrm{m}-$ $\mathrm{Ph}), 7.08\left(\mathrm{~m}, 2 \mathrm{H}, \mathrm{o}-\mathrm{Ph}\right.$ overlapping with $\left.\mathrm{Ar}_{4}\right), 7.06$ (pseudo t, $\left.{ }^{3} J_{\mathrm{H}-\mathrm{H}}=7.9 \mathrm{~Hz}, 1 \mathrm{H}, \mathrm{Ar} \mathrm{H} \mathrm{H}_{4}\right), 6.70\left(\mathrm{~d},{ }^{3} \mathrm{~J}_{\mathrm{H}-\mathrm{H}}=7.9\right.$ $\mathrm{Hz}, 1 \mathrm{H}, \mathrm{Ar} \mathrm{H}_{3}$ ), 6.46 (pseudo t, ${ }^{3} \mathrm{~J}_{\mathrm{H}-\mathrm{H}}=7.2 \mathrm{~Hz}, 1 \mathrm{H}, \mathrm{Ar} \mathrm{H}_{5}$ ), $6.11\left(\mathrm{~d},{ }^{3} \mathrm{~J}_{\mathrm{H}-\mathrm{H}}=7.2 \mathrm{~Hz}, 1 \mathrm{H}, \mathrm{Ar} \mathrm{H} \mathrm{H}_{6}\right), 3.97\left(\mathrm{~s}, 2 \mathrm{H}, \mathrm{ArCH}_{2}\right)$, 3.45 (broad, 4H, $2 \mathrm{NCH}_{2} \mathrm{CH}_{2}$ ), 1.91 (broad, 4H, $\left.\mathrm{NCH}_{2} \mathrm{CH}_{2}\right),-0.76\left(\mathrm{~s}, 6 \mathrm{H}, \mathrm{CH}_{3}\right) .{ }^{13} \mathrm{C}\left\{{ }^{1} \mathrm{H}\right\}$ NMR $(151 \mathrm{MHz}$, $\left.\mathrm{CD}_{2} \mathrm{Cl}_{2}\right), \delta(\mathrm{ppm}): 169.6\left(\mathrm{C}_{\mathrm{q}}, \mathrm{C}=\mathrm{N}\right), 161.3\left(\mathrm{C}_{\mathrm{q}}, \operatorname{Ar} \mathrm{C}-\mathrm{O}\right)$, $133.3\left(\mathrm{C}_{\mathrm{q}}, i-\mathrm{Ph}\right), 130.9(\mathrm{CH}, p-\mathrm{Ph}), 129.6(\mathrm{CH}, m-\mathrm{Ph})$, $129.4\left(\mathrm{CH}, \mathrm{Ar} \mathrm{C}_{4}\right), 128.9\left(\mathrm{C}_{\mathrm{q}}, \mathrm{Ar} \mathrm{C}_{1}\right), 128.1(\mathrm{CH}, \mathrm{o}-\mathrm{Ph})$, $127.9\left(\mathrm{CH}, \mathrm{ArC}_{6}\right), 118.7\left(\mathrm{CH}, \operatorname{Ar} \mathrm{C}_{3}\right), 116.6\left(\mathrm{CH}, \mathrm{Ar} \mathrm{C}_{5}\right)$, $\left.52.8\left(\mathrm{CH}_{2}, \mathrm{ArCH}\right)_{2}\right), 51.6\left(\mathrm{CH}_{2}, \mathrm{NCH}_{2} \mathrm{CH}_{2}\right), 25.6\left(\mathrm{CH}_{2}\right.$, $\mathrm{NCH}_{2} \mathrm{CH}_{2}$ ), -8.8 (broad, $\mathrm{CH}_{3}, \mathrm{AlMe}_{2}$ ).

Synthesis of $\mathbf{3 b}$ (beige solid, $320 \mathrm{mg}$, yield: $76 \%$ ). L3H (1 equiv., $1.80 \mathrm{mmol}, 321 \mathrm{mg}$ ) was dissolved in DCM $(9 \mathrm{~mL})$, and added to trimethylaluminium solution (1 equiv., $2 \mathrm{M}$ in hexanes, $1.80 \mathrm{mmol}, 900 \mu \mathrm{L})$. The mixture was stirred $2 \mathrm{~h}$ at $\mathrm{rt}$. The volatiles were evaporated, and the residual solid was washed with pentane $(2 \times 5 \mathrm{~mL})$ to give 3 b. Elemental Analysis: calcd for $\mathrm{C}_{12} \mathrm{H}_{19} \mathrm{AlN}_{2} \mathrm{O}: \mathrm{C}, 61.52 ; \mathrm{H}, 8.17 ; \mathrm{N}, 11.96 \%$.
Found: C, 60.81; H, 8.10; N, $11.28 \%$ \%. ${ }^{1}$ H NMR (500 $\mathrm{MHz}, \mathrm{CD}_{2} \mathrm{Cl}_{2}$ ): $\delta(\mathrm{ppm})=7.44$ (s, $1 \mathrm{H}, \mathrm{CH}$ formamidine), 7.15 (pseudo td, ${ }^{3} J_{\mathrm{HH}}=7.7 \mathrm{~Hz},{ }^{4} \mathrm{~J}_{\mathrm{HH}}=1.8 \mathrm{~Hz}, 1 \mathrm{H}, \mathrm{Ar} \mathrm{H} \mathrm{H}_{4}$ ), $7.02\left(\mathrm{dd},{ }^{3} J_{\mathrm{HH}}=7.3 \mathrm{~Hz},{ }^{4} J_{\mathrm{HH}}=1.8 \mathrm{~Hz}, 1 \mathrm{H}, \operatorname{Ar~H}\right)_{6}, 6.75(\mathrm{~d}$, ${ }^{3} J_{\mathrm{HH}}=8.0 \mathrm{~Hz}, 1 \mathrm{H}, \mathrm{Ar} \mathrm{H}_{3}$ ), 6.66 (pseudo $\mathrm{t}^{3}{ }^{3} \mathrm{HHH}_{\mathrm{HH}}=7.4 \mathrm{~Hz}$, $\left.1 \mathrm{H}, \mathrm{Ar} \mathrm{H}_{5}\right), 4.30$ (s, 2H, $\mathrm{ArCH}_{2}$ ), 3.05 (s, 6H, $\left.\mathrm{NMe}_{2}\right),-0.81$ (s, 6H, AlMe $).{ }^{13} \mathrm{C}\left\{{ }^{1} \mathrm{H}\right\}$ NMR $\left(126 \mathrm{MHz}, \mathrm{CD}_{2} \mathrm{Cl}_{2}\right): \delta$ $(\mathrm{ppm})=160.7\left(\mathrm{C}_{\mathrm{q}}, \operatorname{Ar} \mathrm{C}-\mathrm{O}\right.$ overlapping with $\left.\mathrm{C}=\mathrm{N}\right)$, 160.5 (broad, $\mathrm{C}_{q}, \mathrm{C}=\mathrm{N}$ overlapping with $\operatorname{Ar} \mathrm{C}-\mathrm{O}$ ), 130.0 $\left(\mathrm{CH}, \mathrm{ArC}_{4}\right), 128.4\left(\mathrm{C}_{\mathrm{q}}, \mathrm{ArC}_{1}\right), 127.6\left(\mathrm{CH}, \mathrm{ArC}_{6}\right), 119.2$ $\left(\mathrm{CH}, \mathrm{Ar} \mathrm{C}_{3}\right), 117.3\left(\mathrm{CH}, \mathrm{ArC} \mathrm{C}_{5}\right), 58.2\left(\mathrm{CH}_{2}, \mathrm{ArCH}_{2}\right), 42.2$ (broad, $\mathrm{CH}_{3}$, NMe overlapping with NMe), 39.3 (broad, $\mathrm{CH}_{3}$, NMe overlapping with NMe), -8.1 (broad, $\mathrm{CH}_{3}$, $\mathrm{AlMe}_{2}$ ).

Synthesis of 4b (beige powder, $320 \mathrm{mg}$, yield: $85 \%$ ). Same procedure than for $\mathbf{3 b}$. Elemental Analysis: calcd for $\mathrm{C}_{13} \mathrm{H}_{21} \mathrm{AlN}_{2} \mathrm{O}: \mathrm{C}, 62.88 ; \mathrm{H}, 8.52 ; \mathrm{N}, 11.28 \%$. Found: C, 62.05; H, 8.47; N, $10.36 \%$. HRMS (ESI-pos): calcd for $\left[\mathrm{C}_{13} \mathrm{H}_{22} \mathrm{AlN}_{2} \mathrm{O}\right]^{+}[\mathrm{M}+\mathrm{H}]^{+}: 249.15420$. Found: 249.15355 (-2.6 ppm). ${ }^{1} \mathrm{H}$ NMR $\left(500 \mathrm{MHz}, \mathrm{CD}_{2} \mathrm{Cl}_{2}\right): \delta$ $\left(\right.$ ppm) $=7.11$ (pseudo td, ${ }^{3} J_{\mathrm{HH}}=7.7 \mathrm{~Hz},{ }^{4} J_{\mathrm{HH}}=1.8 \mathrm{~Hz}$, $\left.1 \mathrm{H}, \mathrm{Ar} \mathrm{H} \mathrm{H}_{4}\right), 7.04\left(\mathrm{dd},{ }^{3} \mathrm{~J}_{\mathrm{HH}}=7.3 \mathrm{~Hz},{ }^{4} J_{\mathrm{HH}}=1.8 \mathrm{~Hz}, 1 \mathrm{H}, \mathrm{Ar}\right.$ $\left.\mathrm{H}_{6}\right), 6.69\left(\mathrm{~d},{ }^{3} \mathrm{~J}_{\mathrm{HH}}=8.0 \mathrm{~Hz}, 1 \mathrm{H}, \mathrm{Ar} \mathrm{H} \mathrm{H}_{3}\right), 6.63$ (pseudo t, $\left.3 \mathrm{JHH}_{\mathrm{H}}=7.3 \mathrm{~Hz}, 1 \mathrm{H}, \mathrm{Ar} \mathrm{H} \mathrm{H}\right), 4.23\left(\mathrm{~s}, 2 \mathrm{H}, \mathrm{ArCH}_{2}\right), 3.09(\mathrm{~s}$, $\left.6 \mathrm{H}, \mathrm{NMe}_{2}\right), 2.17\left(\mathrm{~s}, 3 \mathrm{H}, \mathrm{CH}_{3}\right.$ acetamidine), $-0.86(\mathrm{~s}, 6 \mathrm{H}$, AlMe $\left.{ }_{2}\right) \cdot{ }^{13} \mathbf{C}\left\{{ }^{1} \mathrm{H}\right\}$ NMR (126 MHz, $\left.\mathrm{CD}_{2} \mathrm{Cl}_{2}\right): \delta(\mathrm{ppm})=$ $171.6\left(C_{q}, C=N\right), 161.3\left(C_{q}, \operatorname{Ar~C}-0\right), 129.7\left(C H, A r C_{4}\right)$, $128.4\left(\mathrm{C}_{\mathrm{q}}, \operatorname{Ar} \mathrm{C}_{1}\right), 127.6\left(\mathrm{CH}, \operatorname{Ar} \mathrm{C}_{6}\right), 119.0\left(\mathrm{CH}, \operatorname{Ar} \mathrm{C}_{3}\right)$, 116.7 (CH, Ar $\left.\mathrm{C}_{5}\right), 51.2\left(\mathrm{CH}_{2}, \mathrm{ArCH}_{2}\right), 41.3\left(\mathrm{CH}_{3}, \mathrm{NMe}_{2}\right)$, 16.7 $\left(\mathrm{CH}_{3}\right.$, acetamidine), -9.5 (broad, $\left.\mathrm{CH}_{3}, \mathrm{AlMe}_{2}\right)$.

\section{ASSOCIATED CONTENT}

\section{Supporting Information}

The Supporting Information is available free of charge on the ACS Publications website.

NMR spectra of compounds $\mathbf{L} \mathbf{H}-\mathbf{L} \mathbf{4 H},\left[\mathbf{L} \mathbf{1} \mathbf{H}_{2}\right][\mathbf{B r}]$, L1Na, 1a-4a, 1a' and 1b-4b. ${ }^{1} \mathrm{H}$ NMR monitoring of the evolution of $\mathbf{L 1 H}$ into 2-Phenyl-4H-1,3-benzoxazine.

Tables of crystal data for the proligands $\left[\mathbf{L} \mathbf{H}_{2}\right][\mathrm{Br}]$, $\mathbf{L} \mathbf{2 H}$ and for the complexes 1a, 2a, 1a', 1a", $\mathbf{1 b}$ and $\mathbf{2 b}$.

Graph of the PLA $M_{\mathrm{n}}$ values as a function of lactide conversion, Graph of $\operatorname{In}\left([\mathrm{M}]_{0} /[\mathrm{M}]\right)$ versus time, GPC analysis, MALDI-TOF spectra. 


\section{Accession Codes}

CCDC 1868743, 1868745-1868750 and 1937786 contain the Supporting crystallographic data for this paper. These data can be obtained free of charge via www.ccdc.cam.ac.uk/data_request/cif, or by emailing data request@ccdc.cam.ac.uk, or by contacting The Cambridge Crystallographic Data Centre, 12 Union Road, Cambridge CB2 1EZ, UK; fax: +44 1223336033.

\section{AUTHOR INFORMATION}

\section{Corresponding Authors}

* E-mail: dagorne@unistra.fr,_Tel: +33 (0)3 688515 30; pierre.le-gendre@u-bourgogne.fr, Tel: +33 (0)3 80 3960 82;

\section{Notes}

The authors declare no competing financial interest.

\section{ACKNOWLEDGMENTS}

Support was provided by the Ministère de I'Enseignement Supérieur et de la Recherche, and the Centre National de la Recherche Scientifique (CNRS). This work is part of the project CHIMIE DURABLE, ENVIRONNEMENT ET AGROALIMENTAIRE, supported by the Université de Bourgogne, Conseil Régional de Bourgogne through the plan d'actions régional pour I'innovation (PARI) and the European Union through the PO FEDER-FSE Bourgogne 2014/2020 programs.

\section{REFERENCES}

(1) Phenoxyimine metal complexes for olefin polymerization, for a review see: (a) Makio, H.; Terao, H.; Iwashita, A.; Fujita, T. FI Catalysts for Olefin Polymerization-A Comprehensive Treatment. Chem. Rev. 2011, 111, 2363-2449. For representative examples see: (b) Saito, J.; Mitani, M.; Matsui, S.; Sugi, M.; Tohi, Y.; Tsutsui, T.; Fujita, T.; Nitabaru, M.; Makio, H. (Mitsui Chemicals). Olefin polymerization catalysts, transition metal compounds, processes for olefin polymerization, and Alpha-olefin/conjugated diene copolymers, European Patent Application EP0874005, 1997. (c) Johnson, L. K.; Bennett, A. M.; Ittel, S. D.; Wang, L.; Parthasarathy, A.; Hauptman, E.; Simpson, R. D.; Feldman, J.; Coughlin, E. B. (Du Pont De Nemours and Company). Polymerisation of olefins.
WO Patent 9830609, 1998. (d) Bansleben, D. A.; Friedriich, S. K.; Younkin, T. D.; Grubbs, R. H.; Wang, C.; Li, R. T. (W.R. Grace \& Co.-Conn.). Catalysts compositions and processes for polymers and copolymers. WO Patent 9842664, 1998. (e) Wang, C.; Friedrich, S.; Younkin, T. R.; Li, R. T.; Grubbs, R. H.; Bansleben, D. A.; Day, M. W. Neutral Nickel(II)-Based Catalysts for Ethylene Polymerization. Organometallics 1998, 17, 3149-3151. (f) Younkin, T. R.; Connor, E. F.; Henderson, J. I.; Friedrich, S. K.; Grubbs, R. H.; Bansleben, D. A. Neutral, SingleComponent Nickel (II) Polyolefin Catalysts That Tolerate Heteroatoms. Science 2000, 287, 460-462. (g) Cai, Z.; Xiao, D.; Do, L. H. Fine-Tuning Nickel Phenoxyimine Olefin Polymerization Catalysts: Performance Boosting by Alkali Cations. J. Am. Chem. Soc. 2015, 137, 15501-15510. (h) Gao, Y.; Christianson, M. D.; Wang, Y.; Chen, J.; Marshall, S.; Klosin, J.; Lohr, T. L.; Marks, T. J. Unexpected Precatalyst sigma-Ligand Effects in Phenoxyimine ZrCatalyzed Ethylene/1-Octene Copolymerizations. J. Am. Chem. Soc. 2019, 141, 7822-7830.

(2) For representative examples of phenoxyimine metal complexes for ROP of cyclic esters, see: (a) Nomura, N.; Aoyama, T.; Ishii, R.; Kondo, T. Salicylaldimine-Aluminum Complexes for the Facile and Efficient Ring-Opening Polymerization of $\varepsilon$ Caprolactone. Macromolecules 2005, 38, 5363-5366. (b) Chen, H.-Y.; Tang, H.-Y.; Lin, C.-C. Ring-Opening Polymerization of Lactides Initiated by Zinc Alkoxides Derived from NNO-Tridentate Ligands. Macromolecules 2006, 39, 3745-3752. (c) Liu, J.; Iwasa, N.; Nomura, K. Synthesis of Al complexes containing phenoxy-imine ligands and their use as the catalyst precursors for efficient living ring-opening polymerisation of $\varepsilon$-caprolactone. Dalton Trans. 2008, 3978-3988. (d) Pappalardo, D.; Annunziata, L.; Pellecchia, C. Living Ring-Opening Homo- and Copolymerization of $\varepsilon$-Caprolactone and $L-$ and $D, L-$ Lactides by Dimethyl(salicylaldiminato)aluminum Compounds. Macromolecules 2009, 42, 6056-6062. (e) García-Valle, F. M.; Tabernero, V.; Cuenca, T.; Mosquera, M. E. G.; Cano, J.; Milione, S. Biodegradable PHB from rac- $\beta$-Butyrolactone: Highly Controlled ROP Mediated by a Pentacoordinated Aluminum Complex. Organometallics 2018, 37, 83784. 
(3) (a) Manna, K.; Zhang, T.; Carboni, M.; Abney, C. W.; Lin, W. Salicylaldimine-Based Metal-Organic Framework Enabling Highly Active Olefin Hydrogenation with Iron and Cobalt Catalysts. J. Am. Chem. Soc. 2014, 136, 13182-13185. (b) Jia, W.-G.; Zhang, H.; Zhang, T.; Xie, D.; Ling, S.; Sheng, E.-H. HalfSandwich Ruthenium Complexes with Schiff-Base Ligands: Syntheses, Characterization, and Catalytic Activities for the Reduction of Nitroarenes. Organometallics 2016, 35, 503-512.

(4) Yang, H.-L.; Cai, P.; Liu, Q.-H.; Yang, X.-L.; Fang, S.Q.; Tang, Y.-W.; Wang, C.; Wang, X.-B.; Kong, L.-Y. Design, synthesis, and evaluation of salicyladimine derivatives as multitarget-directed ligands against Alzheimer's disease. Biorg. Med. Chem. 2017, 25, 5917-5928.

(5) Hoshino, N. Liquid crystal properties of metalsalicylaldimine complexes: Chemical modifications towards lower symmetry. Coord. Chem. Rev. 1998, $174,77-108$.

(6) Chang, M.-C.; Lu, W.-Y.; Chang, H.-Y.; Lai, Y.-C.; Chiang, M. Y.; Chen, H.-Y.; Chen, H.-Y. Comparative Study of Aluminum Complexes Bearing N,O- and N,SSchiff Base in Ring-Opening Polymerization of $\varepsilon$ Caprolactone and I-Lactide. Inorg. Chem. 2015, 54, 11292-11298.

(7) Liu, X.; Gao, W.; Mu, Y.; Li, G.; Ye, L.; Xia, H.; Ren, Y.; Feng, S. Dialkylaluminum Complexes with Chelating Anilido-Imine Ligands: Synthesis, Structures, and Luminescent Properties. Organometallics 2005, 24, 1614-1619.

(8) (a) Hogerheide, M. P.; Wesseling, M.; Jastrzebski, J. T. B. H.; Boersma, J.; Kooijman, H.; Spek, A. L.; van Koten, G. Versatility in Phenolate Bonding in Organoaluminum Complexes Containing Mono- and Bis-ortho-Chelating Phenolate Ligands. X-ray Structures of $\mathrm{Al}\left\{\mathrm{OC}_{6} \mathrm{H}_{2}\left(\mathrm{CH}_{2} \mathrm{NMe}_{2}\right)_{2}-2,6-\mathrm{Me}-4\right\}_{3}$, $\mathrm{Al}(\mathrm{Me})_{2}\left\{\mathrm{OC}_{6} \mathrm{H}_{2}\left(\mathrm{CH}_{2} \mathrm{NMe}_{2}\right)_{2}-2,6-\mathrm{Me}-4\right\} \cdot \mathrm{N}-\mathrm{AlMe}_{3}$, and $\mathrm{Al}(\mathrm{Me})_{2}\left\{\mathrm{OC}_{6} \mathrm{H}_{2}\left(\mathrm{CH}_{2} \mathrm{NMe}_{2}\right) 2-2,6-\mathrm{Me}-4\right\} \cdot \mathrm{N}-\mathrm{AlMe}_{3} \cdot \mathrm{O}-$

$\mathrm{AlMe}_{3}$ Organometallics 1995, 14, 4483-4492. (b) Dagorne, S.; Lavanant, L.; Chassenieux, C.; Haquette, P.; Jaouen, G. Organometallics 2003, 22, 3732-3741. (c) Dagorne, S.; Le Bideau F.; Welter, R.; BelleminLaponnaz, S.; Maisse-François, A. Well-Defined Cationic Alkyl- and Alkoxide-Aluminum Complexes and Their Reactivity with $\varepsilon$-Caprolactone and Lactides. Chem. Eur. J. 2007, 13, 3202-3217.

(9) Cheisson, T.; Cao, T.-P.-A.; Le Goff, X. F.; Auffrant, A. Nickel Complexes Featuring IminophosphoranePhenoxide Ligands for Catalytic Ethylene Dimerization. Organometallics 2014, 33, 6193-6199.

(10) (a) Waltman, A. W.; Grubbs, R. H. A New Class of Chelating N-Heterocyclic Carbene Ligands and Their Complexes with Palladium. Organometallics 2004, 23, 3105-3107. (b) Seok Oh, C.; Won Lee, C.; Yeob Lee, J. Simple heteroatom engineering for tuning the triplet energy of organometallic host materials for red, green and blue phosphorescent organic light-emitting diodes. Chem. Commun. 2013, 49, 3875-3877. (c) Zhang, Y.; Gao, A.; Zhang, Y.; Xu, Z.; Yao, W. Aluminum complexes with benzoxazolphenolate ligands: Synthesis, characterization and catalytic properties for ring-opening polymerization of cyclic esters. Polyhedron 2016, 112, 27-33. (d) Sarada, G.; Sim, B.; Cho, W.; Yoon, J.; Gal, Y.-S.; Kim, J.-J.; Jin, S.-H. New sky-blue and bluish-green emitting Ir(III) complexes containing an azoline ancillary ligand for highly efficient PhOLEDs. Dyes and Pigments 2016, 131, 6068. (e) Li, M.; Shu, X.; Cai, Z.; Eisen, M. S. Synthesis, Structures, and Norbornene Polymerization Behavior of Neutral Nickel(II) and Palladium(II) Complexes Bearing Aryloxide Imidazolidin-2-imine Ligands. Organometallics 2018, 37, 1172-1180.

(11) Hegarty, A. F.; Chandler, A. Isomerisation about the $\mathrm{C}-\mathrm{N}$ and $\mathrm{C}=\mathrm{N}$ bonds of $\mathrm{E}$ - and Z-amidines. J. Chem. Soc., Chem. Commun. 1980, 130-131.

(12) (a) Coles, M. P. Application of neutral amidines and guanidines in coordination chemistry. Dalton Trans. 2006, 985-1001. (b) Panda, T. K.; Tsurugi, H.; Pal, K.; Kaneko, H.; Mashima, K. Highly Reactive Metal-Nitrogen Bond Induced $\mathrm{C}-\mathrm{H}$ Bond Activation and Azametallacycle Formation. Organometallics 2010, 29, 34-37. (c) Rad'kov, V.; Roisnel T.; Trifonov A. ; Carpentier, J.-F.; Kirillov E. Neutral and Cationic Alkyl and Amido Group 3 Metal Complexes of Amidine-Amidopyridinate Ligands: Synthesis, Structure, and Polymerization Catalytic Activity. Eur. J. Inorg. Chem. 2014, 2014, 4168-4178. (d) Lapshin, I. V.; Yurova, O. S.; Basalov, I. V.; Rad'kov, V. Y.; Musina, E. I.; Cherkasov, A. V.; Fukin, G. K.; Karasik, A. A.; 
Trifonov, A. A. Amido $\mathrm{Ca}$ and $\mathrm{Yb}$ (II) Complexes Coordinated by Amidine-Amidopyridinate Ligands for Catalytic Intermolecular Olefin Hydrophosphination. Inorg. Chem. 2018, 57, 2942-2952.

(13) For a review see: (a) Edelmann, F. T. Lanthanide amidinates and guanidinates: from laboratory curiosities to efficient homogeneous catalysts and precursors for rare-earth oxide thin films. Chem. Soc. Rev. 2009, 38, 2253-2268. For representative examples, see: (b) Stewart, P. J.; Blake, A. J.; Mountford, P. New Titanium Complexes Containing an Amidinate-Imide Supporting Ligand Set: Cyclopentadienyl, Alkyl, Borohydride, Aryloxide, and Amide Derivatives. Organometallics 1998, 17, 32713281. (c) Aharonovich, S.; Kapon, M.; Botoshanski, M.; Eisen, M. S. N, N'-Bis-Silylated Lithium Aryl Amidinates: Synthesis, Characterization, and the Gradual Transition of Coordination Mode from $\sigma$ Toward $\pi$ Originated by Crystal Packing Interactions. Organometallics 2008, 27, 1869-1877. (d) Weitershaus, K.; Ward, B. D.; Kubiak, R.; Müller, C.; Wadepohl, H.; Doye, S.; Gade, L. H. Titanium hydroamination catalysts bearing a 2aminopyrrolinato spectator ligand: monitoring the individual reaction steps. Dalton Trans. 2009, 45864602. (e) Hong, J.; Zhang, L.; Wang, K.; Chen, Z.; Wu, L.; Zhou, X. Synthesis, Structural Characterization, and Reactivity of Mono(amidinate) Rare-Earth-Metal Bis(aminobenzyl) Complexes. Organometallics 2013, 32, 7312-7322. (f) Collins, R. A.; Russell, A. F.; Scott, R. T. W.; Bernardo, R.; van Doremaele, G. H. J.; Berthoud, A.; Mountford, P. Monometallic and Bimetallic Titanium $\mathrm{K}^{1}$-Amidinate Complexes as Olefin Polymerization Catalysts. Organometallics 2017, 36, 2167-2181. (g) Wei, J.; Duman, L. M.; Redman, D. W.; Yonke, B. L.; Zavalij, P. Y.; Sita, L. R. N-Substituted Iminocaprolactams as Versatile and Low Cost Ligands in Group 4 Metal Initiators for the Living Coordinative Chain Transfer Polymerization of $\alpha$-Olefins. Organometallics 2017, 36, 4202-4207. (h) Rios Yepes, Y.; Quintero, C.; Osorio Meléndez, D.; Daniliuc, C. G.; Martínez, J.; Rojas, R. S. Cyclic Carbonates from $\mathrm{CO}_{2}$ and Epoxides Catalyzed by Tetra- and Pentacoordinate Amidinate Aluminum Complexes. Organometallics 2018, 38, 469-478.(i) Kaufmann, S.; Radius, M.; Moos, E.; Breher, F.; Roesky, P. W. Rhodium(I) and Iridium(I) Complexes of Ferrocenyl-
Functionalized Amidinates and Bis(amidinates): $\mathrm{K}^{2} \mathrm{~N}$ Coordination Versus Ferrocenyl Ortho-Metalation. Organometallics 2019, 38, 1721-1732.

(14) (a) Sinenkov, M.; Kirillov, E.; Roisnel, T.; Fukin, G.; Trifonov, A.; Carpentier, J.-F. Rare-Earth Complexes with Multidentate Tethered Phenoxy-Amidinate Ligands: Synthesis, Structure, and Activity in RingOpening Polymerization of Lactide. Organometallics 2011, 30, 5509-5523. (b) Kirillov, E.; Roisnel, T.; Carpentier, J.-F. Synthesis and Structural Diversity of Group 4 Metal Complexes with Multidentate Tethered Phenoxy-Amidine and Phenoxy-Amidinate Ligands. Organometallics 2012, 31, 3228-3240.

(15) Representative reviews on metal-mediated lactide ROP catalysis: (a) O'Keefe, B. J.; Hillmyer, M. A.; Tolman, W. B. Polymerization of lactide and related cyclic esters by discrete metal complexes. J. Chem. Soc., Dalton Trans. 2001, 2215-2224; (b) DechyCabaret, O.; Martin-Vaca, B.; Bourissou, D. Controlled Ring-Opening Polymerization of Lactide and Glycolide. Chem. Rev. 2004, 104, 6147-6176; (c) Platel, R. H.; Hodgson, L. M.; Williams, C. K. Biocompatible Initiators for Lactide Polymerization. Polym. Rev. 2008, 48, 11-63; (d) Thomas, C. M. Stereocontrolled ring-opening polymerization of cyclic esters: synthesis of new polyester microstructures. Chem. Soc. Rev. 2010, 39, 165-173; (e) Stanford, M. J.; Dove, A. P. Stereocontrolled ring-opening polymerisation of lactide. Chem. Soc. Rev. 2010, 39, 486-494; (f) Buffet, J.-C.; Okuda, J. Initiators for the stereoselective ringopening polymerization of meso-lactide. Polym. Chem. 2011, 2, 2758-2763; (g) Sauer, A.; Kapelski, A.; Fliedel, C.; Dagorne, S.; Kol, M.; Okuda, J. Structurally well-defined group 4 metal complexes as initiators for the ring-opening polymerization of lactide monomers. Dalton Trans. 2013, 42, 9007-9023; (h) Dagorne, S.; Normand, M.; Kirillov, E.; Carpentier, J.-F. Gallium and indium complexes for ring-opening polymerization of cyclic ethers, esters and carbonates. Coord. Chem. Rev. 2013, 257, 1869-1886; (i) Guillaume, S. M.; Kirillov, E.; Sarazin, Y.; Carpentier, J.-F. Beyond Stereoselectivity, Switchable Catalysis: Some of the Last Frontier Challenges in Ring-Opening Polymerization of Cyclic Esters. Chem. Eur. J. 2015, 21, 7988-8003. (j) Le Roux, E. Recent advances on tailormade titanium catalysts for biopolymer synthesis. Coord. Chem. Rev. 2016, 306, Part 1, 65-85. 
(16) (a) Dunn, P. J.: 5.19 - Amidines and N-Substituted Amidines. In Comprehensive Organic Functional Group Transformations II; Katritzky, A. R., Taylor, R. J. K., Eds.; Elsevier: Oxford, 2005; pp 655-699. (b) Aly, A. A.; Nour-El-Din, A. M. Functionality of amidines and amidrazones, Arkivoc 2008, (i), 153-194.

(17) Toste, D.; McNulty, J.; Still, I. W. J. Formamidine as a Versatile Protecting Group for Primary Amines: A Mild Procedure for Hydrolytic Removal. Synth. Commun. 1994, 24, 1617-1624.

(18) Comparison between the $\mathrm{NMe}_{2}$ signal profiles in the ${ }^{1} \mathbf{H}$ NMR spectra of $\mathbf{L} \mathbf{H}, \mathbf{L} \mathbf{L H}$ and $\mathbf{L} \mathbf{H}$ should be taken with caution since the spectra have not been registered in the same conditions (deuterated solvent, NMR magnetic field).

(19) Rotational barrier was calculated from the dynamic exchange between $\mathrm{H} \alpha$ protons. Rotational barriers of $61.6(5) \mathrm{kJ} \mathrm{mol}^{-1}$ and $52.2(5) \mathrm{kJ} \mathrm{mol}^{-1}$ were calculated from the dynamic exchange between $\mathrm{H} \beta$ protons of the pyrrolidine ring in the proligand $\mathbf{L} \mathbf{2 H}$ and in the complex $\mathbf{2 b}$, respectively. ${ }^{1} \mathrm{H}$ NMR spectra were recorded every $5 \mathrm{~K}$. The coalescence temperatures were chosen at the center of the interval where coalescence occurred. To determine the uncertainties due to the temperature we suppose an uniform distribution over the $5 \mathrm{~K}$ interval. The uncertainty due to the frequencies are negligible. As usual, expanded uncertainties are given at the 95\% confidence level.

(20) McKennis, J. S.; Smith, P. A. S. Restricted rotation in benzamidinium systems. J. Org. Chem. 1972, 37, 4173-4178.

(21) Wawer, I. Hindered rotation in amidines. J. Mol. Struct. 1990, 218, 165-167.

(22) Oszczapowicz, J.; Wawer, I.; Dargatz, M.; Kleinpeter, E. Amidines. Part $34 .{ }^{15} \mathrm{~N}$ NMR spectra of trisubstituted amidines. Substituent effects. J. Chem. Soc., Perkin Trans. 2 1995, 1127-1131.

(23) Rotational barrier of $56.6(5) \mathrm{kJ} \mathrm{mol}^{-1}$ was calculated from the dynamic exchange between $\mathrm{H} \alpha$ protons of the ethyl ligand in $\mathbf{1 a}$.

(24) The dissociation of the dinuclear complex 1a into the mononuclear form decreased the steric constraints around the phenoxyamidine ligand enabling faster flipping motion of the metallacycle and the non-persistence of the $\mathrm{sp}^{2}$-sp $\mathrm{sp}^{3}$ atropoisomeric chirality in the monomer even at low temperature. Therefore, no diastereotopic splitting of the methylene protons is observed for the monomer.

(25) Bouyhayi, M.; Sarazin, Y.; Casagrande Jr, O. L.; Carpentier, J.-F. Aluminum, calcium and zinc complexes supported by potentially tridentate iminophenolate ligands: synthesis and use in the ringopening polymerization of lactide. Appl. Organomet. Chem. 2012, 26, 681-688.

(26) An analogous spiro Zinc complex with phenoxyimine ligands has been previously described, see: Chisholm, M. H.; Gallucci, J. C.; Zhen, H.; Huffman, J. C. Three-Coordinate Zinc Amide and Phenoxide Complexes Supported by a Bulky Schiff Base Ligand. Inorg. Chem. 2001, 40, 5051-5054.

(27) For a review see: (a) Wheaton, C. A.; Hayes, P. G.; Ireland, B. J. Complexes of $\mathrm{Mg}, \mathrm{Ca}$ and $\mathrm{Zn}$ as homogeneous catalysts for lactide polymerization. Dalton Trans. 2009, 4832-4846. For representative examples, see: (b) Chamberlain, B. M.; Cheng, M.; Moore, D. R.; Ovitt, T. M.; Lobkovsky, E. B.; Coates, G. $W$. Polymerization of Lactide with Zinc and Magnesium $\beta$-Diiminate Complexes: Stereocontrol and Mechanism. J. Am. Chem. Soc. 2001, 123, 32293238. (c) Williams, C. K.; Breyfogle, L. E.; Choi, S. K.; Nam, W.; Young, V. G.; Hillmyer, M. A.; Tolman, W. B. A Highly Active Zinc Catalyst for the Controlled Polymerization of Lactide. J. Am. Chem. Soc. 2003, 125, 11350-11359. (d) Yu, X.-F.; Zhang, C.; Wang, Z.-X. Rapid and Controlled Polymerization of rac-Lactide Using N,N,O-Chelate Zinc Enolate Catalysts. Organometallics 2013, 32, 3262-3268; (e) Kan, C.; Hu, J.; Huang, Y.; Wang, H.; Ma, H. Highly Isoselective and Active Zinc Catalysts for rac-Lactide Polymerization: Effect of Pendant Groups of Aminophenolate Ligands. Macromolecules 2017, 50, 7911-7919.

(28) Hung, W.-C.; Huang, Y.; Lin, C.-C. Efficient initiators for the ring-opening polymerization of $\mathrm{L}-$ lactide: Synthesis and characterization of NNOtridentate Schiff-base zinc complexes. J. Polym. Sci., Part A: Polym. Chem. 2008, 46, 6466-6476. 
(29) Normand, M.; Dorcet, V.; Kirillov, E.; Carpentier, J.-F. \{Phenoxy-imine\}aluminum versus -indium Complexes for the Immortal ROP of Lactide: Different Stereocontrol, Different Mechanisms. Organometallics 2013, 32, 1694-1709.

(30) Iwasa, N.; Fujiki, M.; Nomura, K. Ring-opening polymerization of various cyclic esters by Al complex catalysts containing a series of phenoxy-imine ligands: Effect of the imino substituents for the catalytic activity. J. Mol. Catal. A: Chem. 2008, 292, 67-75.

(31) Zhang, W.; Wang, Y.; Sun, W.-H.; Wang, L.; Redshaw, C. Dimethylaluminium aldiminophenolates: synthesis, characterization and ring-opening polymerization behavior towards lactides. Dalton Trans. 2012, 41, 11587-11596.

(32) Dagorne, S.; Fliedel C. Organoaluminum Species in Homogeneous Polymerization Catalysis. Top. Organomet. Chem., 2013, 41, 125-172.
(33) Zelli, R.; Zeinyeh, W.; Haudecoeur, R.; Alliot, J.; Boucherle, B.; Callebaut, I.; Décout, J.-L. A One-Pot Synthesis of Highly Functionalized Purines. Org. Lett. 2017, 19, 6360-6363.

(34) Dolomanov, O. V.; Bourhis, L. J.; Gildea, R. J.; Howard, J. A. K.; Puschmann, H. OLEX2: a complete structure solution, refinement and analysis program. J. Appl. Crystallogr. 2009, 42, 339-341.

(35) Sheldrick, G. SHELXT - Integrated space-group and crystal-structure determination. Acta Crystallographica Section A 2015, 71, 3-8.

(36) Sheldrick, G. SHELXL - Crystal structure refinement with SHELXL. Acta Crystallographica Section C 2015, 71, 3-8. 
TOC Graphic

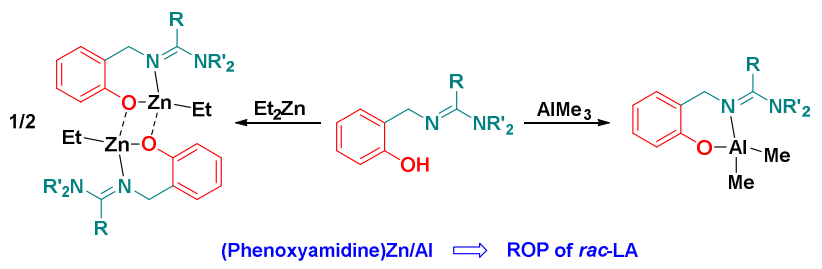

